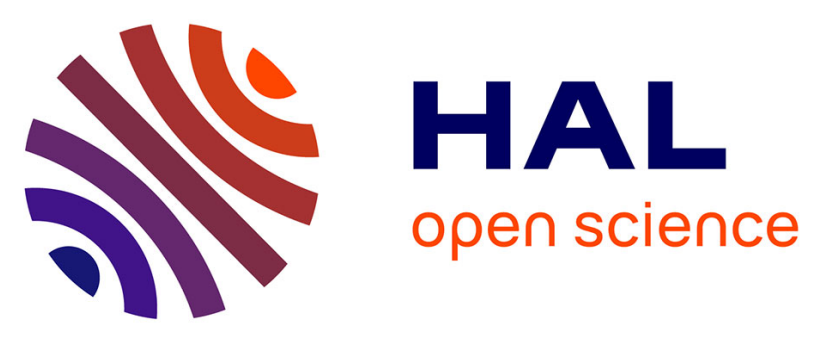

\title{
Exploration of individual variability to better predict the nutrient requirements of gestating sows
}

Charlotte Gaillard, Raphaël Gauthier, Laetitia Cloutier, Jean-Yves Dourmad

\section{To cite this version:}

Charlotte Gaillard, Raphaël Gauthier, Laetitia Cloutier, Jean-Yves Dourmad. Exploration of individual variability to better predict the nutrient requirements of gestating sows. Journal of Animal Science, 2019, 97 (12), pp.4934-4945. 10.1093/jas/skz320 . hal-02375170

\author{
HAL Id: hal-02375170 \\ https://hal.science/hal-02375170
}

Submitted on 21 Nov 2019

HAL is a multi-disciplinary open access archive for the deposit and dissemination of scientific research documents, whether they are published or not. The documents may come from teaching and research institutions in France or abroad, or from public or private research centers.
L'archive ouverte pluridisciplinaire HAL, est destinée au dépôt et à la diffusion de documents scientifiques de niveau recherche, publiés ou non, émanant des établissements d'enseignement et de recherche français ou étrangers, des laboratoires publics ou privés.

\section{(1) (1) $\$$}

Distributed under a Creative Commons Attribution - NonCommercial - NoDerivatives 44.0 


\section{Exploration of individual variability to better predict the nutrient requirements of}

gestating sows ${ }^{1}$

\section{Gaillard"2, R. Gauthier*, L. Cloutier", J.Y. Dourmad*}

*PEGASE, Agrocampus Ouest, INRA, 35590, Saint-Gilles, France

${ }^{\#}$ CDPQ, G1V4M6, Québec City, Canada

${ }^{1}$ This work is supported by Feed-a-Gene, a project that has received funding from the

European Union's Horizon 2020 research and innovation program under grant agreement No.

633531.

${ }^{2}$ Corresponding author: Charlotte Gaillard. E-mail: charlotte.gaillard@inra.fr

(C) The Author(s) 2019. Published by Oxford University Press on behalf of the American Society of Animal Science. All rights reserved. For permissions, please e-mail: journals.permissions@oup.com.citer ce document 


\section{ABSTRACT}

Sows often receive the same feed during gestation even though their nutrient requirements vary during gestation and among sows. The objective of this study was to report the variability in nutrient requirement among sows and during gestation, in order to develop a precision feeding approach. A dataset of 2511 gestations reporting sow characteristics at insemination and their farrowing performance was used as an input for a Python model, adapted from InraPorc ${ }^{\circledR}$, predicting nutrient requirement during gestation. Total metabolizable energy (ME) requirement increased with increasing litter size, gestation weeks, and parity (30.6, 33.6 and $35.5 \mathrm{MJ} / \mathrm{d}$ for parity 1,2 and 3 and beyond, respectively, $P<0.01)$. Standardized ileal digestible lysine (SID Lys) requirement per kg of diet increased from week 1 to 6 of gestation, remained stable from week 7 to 10 , and increased again from week 11 until the end of gestation $(P<0.01)$. Average Lys requirement increased with increasing litter size (SID Lys: $3.00,3.27,3.50 \mathrm{~g} / \mathrm{kg}$ for small, medium and large litters, $P<0.01$ ) and decreased when parity increased (SID Lys: $3.61,3.17,2.84 \mathrm{~g} / \mathrm{kg}$ for parity 1,2 and $3++, P<$ 0.01). Standardized total tract digestible phosphorus (STTD-P) and total calcium (Total-Ca) requirements markedly increased after week 9, with litter size, and decreased when parity increased (STTD-P: 1.36 vs $1.31 \mathrm{~g} / \mathrm{kg}$ for parity 1 and parity 3 and beyond; Total-Ca: 4.28 vs. $4.10 \mathrm{~g} / \mathrm{kg}$ for parity 1 and parity 3 and beyond, $P<0.01)$. Based on empirical cumulative distribution functions, a 4-diets strategy, varying in SID Lys and STTD-P content according to parity and gestation period (P1 from week 0 to $11, \mathrm{P} 2$ from week 12 to 17 ), may be put forward to meet the requirements of $90 \%$ of the sows (two diets for multiparous sows: P1: 2.8 g SID Lys/kg and $1.1 \mathrm{~g}$ STTD-P/kg; P2: $4.5 \mathrm{~g}$ SID Lys/kg and $2.3 \mathrm{~g}$ STTD-P/kg; and two diets for primiparous sows: P1: 3.4 g SID Lys/kg and 1.1g STTD-P/kg; P2: 5.0 g SID Lys/kg, $2.2 \mathrm{~g} \mathrm{STTD}-\mathrm{P} / \mathrm{kg}$ ). Better considering the high variability of sow requirement should thus make it possible to optimize their performance whilst reducing feeding cost and excretion. 
Feeding sows closer to their requirement may initially be achieved by grouping and feeding sows according to gestation week and parity, and ultimately by feeding sows individually using a smart feeder allowing the mixing of different feeds differing in their nutrient content.

Keywords: gestation, individual variability, modelling, nutrition, requirements, sow 


\section{INTRODUCTION}

Nutrient requirement for sows is relatively variable throughout gestation (NRC, 2012). At the end of gestation, requirements for energy (Noblet et al., 1987), amino acids (King and Brown, 1993; Dourmad and Etienne, 2002; NRC, 2012) and minerals (Jondreville and Dourmad, 2005; NRC, 2012) are much higher than in early gestation. These requirements also vary among sows (McPherson et al., 2004; Dourmad et al., 2008) according to their body condition and prolificacy. However, in practice, all sows are generally fed the same standard gestation feed and only feed allowance may vary according to parity, gestation stage and body condition (Young et al., 2004). In all cases, this leads to under or over-feeding situations which may result in a lack of performance and health issues on the one hand, and economic loss and environmental negative effects on the other. There is therefore a need to adjust the feed composition and feeding level of gestating sows more precisely. In practice, this individual fitting ought to be possible thanks to the development of innovative technologies (feeders and sensors), which allow the distribution of tailored rations and provide an increasing number of real-time data on animal characteristics and housing conditions, and the development of mathematical models that predict daily nutrient requirement for each animal as has successfully been done for growing pigs (Cloutier et al., 2015) and lactating sows (Gauthier et al., 2019). For that purpose, it is necessary to dynamically determine the individual nutrient requirement during gestation according to the specific information available for each sow. The objective of this study was thus to develop such a model and use it to explore on the basis of real farm data the within-farm variability in nutrient requirement among sows and over gestation period. 


\section{MATERIAL AND METHODS}

\section{General Approach}

The originality of the approach developed (Fig. 1) is the combination of current knowledge about the nutrient use of sows with the flow of data recorded on-farm, to provide a dynamic determination of optimal nutrient supplies for each sow. These data include (i) insemination events (date of insemination, parity, body weight (BW) and back fat thickness (BT) of sows), (ii) events that occur during gestation (measurements of the physical activity of sows, BW and BT), and (iii) farrowing events (date of farrowing, litter size and piglet birth weight). In practice, the farmer or sensors can record these types of data, which may provide a more accurate and dynamic prediction of nutrient requirement. A mechanistic module based mainly on the InraPorc $®$ model (Dourmad et al., 2008) with some improvements, was used on a daily basis to calculate nutrient requirement. The module calculates daily maintenance costs and gestation costs for each sow, considering its performance. With this approach, nutrient requirement may change according to gestation days, sow performance, and individual farm situation.

\section{Model description}

General approach. The sow model used in this paper is adapted from the InraPorc® model and was applied to the gestation period only. The sow is represented as the sum of different compartments (body lipid, body protein and uterus), the status of these compartments being used to estimate the sow BW and BT. A computerized version of this model based on the set of equations described hereinafter was developed in order to be able to predict the dynamics and the variability in nutrient requirement of a large population of sows.

ME requirements. Total metabolizable energy (ME) requirement was calculated as the sum of the requirements for the maintenance, physical activity and thermoregulation, maternal 
growth and constitution of body reserves, and the development of foetuses and uterine contents (Table 1). First of all, individual average ME requirement was calculated during gestation (Table 1, Eq. 1a). This calculation takes into account maternal BW and BT at insemination and their targets at farrowing, as well as litter size (LS) and the average piglet birth weight. The target of BW after farrowing was determined based on the objective of BW evolution with age, which is defined according to a generalized Weibull function calibrated according to the genotype of the sows on the farm (Dourmad et al., 2008):

The objective of BT at farrowing may depend on farming practices, with the same value being generally used for all parities. Sow BW before farrowing is calculated based on maternal BW and litter weight. The energy retention level to be attained in maternal tissues is calculated according to BW and BT gains during gestation (Table 1, Eq. 14). Energy retention in conceptus is calculated according to litter size (Table 1, Eq. 6). Maintenance requirement is calculated according to the average sow BW during gestation (Table 1, Eq. 2), with possible modulations according to housing conditions and sow activity (Table 1, Eq. 3, 4 and 5) Secondly, nutrient- and energy-use was simulated on a daily basis for each sow assuming that they received the amount of ME corresponding to their individual requirements calculated in the first step. Metabolizable energy intake was partitioned into (i) maintenance requirement, which was predicted according to the BW of sows the previous day (Table 1, Eq. 2), (ii) thermoregulation requirement, depending on the ambient temperature and housing type (group or individual) (Table 1, Eq. 4 and 5), (iii) conceptus growth requirement, which was calculated based on the energy retained in conceptus and the efficiency of the use of ME for uterine growth, and (iv) a remaining fraction utilized for maternal gain, and divided into protein and lipid deposition (Table 1, Eq. 1b). The amount of energy deposited as protein in maternal tissues was calculated (Table 1, Eq. 7) based on maternal nitrogen retention ( $\left.\mathbf{N R}_{\mathbf{m}}\right)$ (Table 1, Eq. 11), determined as the difference between total nitrogen retention (NR) (Table 
1, Eq. 10) and nitrogen retention in conceptus (NR $)$ (Table 1, Eq. 9). The calculation of the amount of lipids deposited $\left(\mathbf{L} \mathbf{I}_{\mathbf{m}}\right)$ or mobilized in maternal tissues was based on the amount of ME remaining or missing and the efficiency of ME for fat deposition, or on the efficiency of energy mobilization from body reserves to provide ME in the case of energy deficits (Table 1, Eq. 8 a and b). Maternal protein $\left(\mathbf{P R}_{\mathbf{m}}\right)$ gain was calculated according to $\mathrm{NR}_{\mathrm{m}}$ (Table 1 , Eq. 12) and maternal lipid gain $\left(\mathbf{L I}_{\mathbf{m}}\right)$ was calculated according to the energy retained in maternal tissue as lipids (Table 1, Eq. 13).

Amino acid $(A A)$ requirements. Maintenance, maternal and conceptus growth requirements were calculated for all essential AA (Table 2, Eq. 17). Maternal AA requirement covers lean tissue growth as well as growth of uterus (Walker and Young, 1992). Maintenance requirement was calculated as the sum of desquamation (skin and hair), minimum turnover and basal endogenous intestinal losses (van Milgen et al., 2008 and NRC, 2012).

Desquamation was estimated for each AA according to sow metabolic BW (Moughan, 1999). Requirement for minimum protein turnover also expressed per kg of metabolic weight reflect the minimum AA catabolism (van Milgen et al., 2008). Basal endogenous losses are composed of the fraction of protein originating from the enzymes secreted in the intestinal tract or from the desquamated intestinal cells which are not reabsorbed by the sow. They depend on dry matter feed intake (Sauvant et al., 2004). As proposed by van Milgen et al. (2008) for growing pigs and by Gauthier et al. (2019) for lactating sows, the maximum marginal efficiencies (kAA) of AA were calculated based on the assumption that the ideal AA profile for gestation was obtained for a sow weighing $200 \mathrm{~kg}$ on average, consuming $2.4 \mathrm{~kg}$ $\mathrm{DM} / \mathrm{d}$, with an average protein retention of 52 and $23 \mathrm{~g} / \mathrm{d}$ in maternal tissues and conceptus, respectively. The maximum efficiency of lysine (Lys) above maintenance was set at 0.72 
(Dourmad et al., 2002; NRC, 2012), from which the $\mathrm{k}_{\mathrm{AA}}$ values of the other AA were calculated and used to calculate standardized ileal digestible AA requirements (Table 3).

Mineral requirements. Standardized total tract digestible phosphorus (STTD-P) and calcium (STTD-Ca) requirements were calculated as the sum of requirements for maintenance, conceptus (foetuses and placenta) growth and maternal body reserves (Table 2, Eq. 18 and 19). Maintenance requirement was determined according to the literature review by Bikker and Blok (2017) and amounted to 7 and $10 \mathrm{mg} / \mathrm{kg} \mathrm{BW}$ for phosphorus and calcium, respectively. The retention of phosphorus in foetuses was calculated based on Jongbloed et al. (2003). The retention of phosphorus in the placenta was assumed to be proportional to protein retention considering a phosphorus to protein ratio of $0.96 \%$ (Jondreville and Dourmad, 2005). Phosphorus requirement for maternal body reserves was calculated according to BW gain and its P content. As proposed by Bikker and Blok (2017) a 0.98 efficiency of STTD-P was used for $\mathrm{P}$ retention and maintenance. Ca retention in conceptus and maternal tissue were calculated according to $\mathrm{P}$ retention based on a $\mathrm{Ca} / \mathrm{P}$ ratio of 1.759 and 1.650 in conceptus and maternal tissues, respectively (Bikker and Blok, 2017). Total calcium (Total-Ca) requirement and Total-Ca/STTD-P ratio were calculated based on a 50\% digestibility assumption for STTD-Ca (Bikker and Blok, 2017).

\section{Database used as an input to the model for the calculation of individual sow nutrient requirement}

A dataset of 2511 gestations from crossbred Landrace x Large White sows, obtained on an experimental farm from 2009 and 2013 was used. It contained the characteristics of sows as regard to their insemination and farrowing performance used as inputs to the model for predicting the individual variability and dynamics of the evolution of nutrient requirement during gestation. This database contained measures of sow body condition (BW and BT) at 
insemination and litter performance (Table 4). An individualized target of BW after farrowing was determined for each sow regarding its age and its BW at insemination using a generalized Weibull function, as described previously, adjusted to the set of data.

BW after farrowing $=275 \times\left(1-\exp \left((-3.824 / 1000) \times(\text { Age at Farrowing })^{0.9801}\right)\right)$ The objective of BT after farrowing was set at $18 \mathrm{~mm}$ for all sows in accordance with the practices of the farm from which the data were collected.

Average ( \pm SD) LS at farrowing was $14.1( \pm 3.3)$ with an average $\mathrm{BW}$ of $1.48 \mathrm{~kg}$ per piglet $( \pm$ $0.24)$, and a total litter weight of $20.5( \pm 4.4) \mathrm{kg}$. The average BW of the sows at insemination increased from 163 to $251 \mathrm{~kg}$ between the first and eighth gestation, while BT at insemination tended to be higher for first and second parity sows and then remained relatively constant (Table 4).

\section{Simulations}

The simulation model was written in Python 3 (Python Software Foundation, Beaverton, Oregon). The Python model was composed of three classes (feed, environment, sow), and one gestation function. The gestation function calculated the growth of the different body compartments, and the nutrient requirements (Fig. 2) for each day and each sow. The sow class inherited the attributes of the feed and environment classes. The inputs for the feed class were the name of the feed, its ME and Standardized ileal digestible (SID) AA contents. The inputs for the environment class were the scenario identification number, room temperature and type of housing. The inputs of the sow class were: identification number, age, parity, LS, average litter BW, sow BW at insemination, sow BW before and after farrowing, and BT at insemination and after farrowing. Two simulations were run with sows housed in groups either at $16^{\circ} \mathrm{C}$ in thermoneutral conditions or at $12^{\circ} \mathrm{C}$, i.e. $4^{\circ} \mathrm{C}$ below the lower critical temperature (LCT). 


\section{Statistical analysis}

For the statistical analysis, the daily data obtained in thermoneutral conditions were averaged into weekly data, and LS was categorized into small (S: LS < 12 piglets), medium (M: $12 \leq$ LS $<16$ piglets) or large litters (L: LS $\geq 16$ piglets). The influence of parity $(1,2,3+)$, LS (S, M, L) and gestation weeks (1 to 16) on sow characteristics (BW, BW gain, PROTm, LIPm), ME, AA, and mineral requirements was analyzed by applying a linear mixed-effect model with the fixed effects of LS, parity, week and their interaction, and the random sow effect. With the R version 3.4.2, the LME function, from the NLME package (Pinheiro et al., 2018), was used to fit the linear mixed-effect models (Laird and Ware, 1982). The correlations over weeks and for each sow were calculated using the temporal corAR1 function, which represents an autocorrelation structure of order 1 (Pinheiro and Bates, 2000). The results are presented in Tables 5 and 6 as means and standard errors for each parity and LS groups, including the P-values to indicate if these two factors and their interactions were significant $(P<0.05)$. When the interactions were not significant, a simplified model without the interactions was applied and the effects were reported in the text (Means \pm SE). The week effect was always significant and was therefore not reported in the tables but described as graphs in the results section.

The temperature effect on ME, feed, AA, and minerals requirements was evaluated using a similar linear mixed-effects model. The results are reported in Table 7 and in the text as means and standard errors.

Cumulative distributions of SID Lys and STTD-P requirements were plotted according to different factors to determine the concentration of SID-Lys and STTD-P needed to meet the requirements of $90 \%$ of the sows. 


\section{RESULTS}

\section{Metabolizable energy requirement}

The average ME requirement of sows is influenced by their BW at insemination $(P<0.001)$, Fig. 3) which shows the importance of taking into account individual variability. Sow BW at insemination accounted for $15 \%$ of the variability in ME requirement, with an average increase of $0.35 \mathrm{MJ} / \mathrm{d} \mathrm{ME}$ for a $10 \mathrm{~kg}$ increase of BW. Average ME requirement during gestation was also affected by BT at mating $(P<0.001)$ with an average increase of 0.66 $\mathrm{MJ} / \mathrm{d} \mathrm{ME}$ for each mm decrease in BT at mating, contributing to $67 \%$ of the variability. Litter size contributed to $10 \%$ of the variability of ME requirement $(P<0.001)$, with an average increase of 0.29 MJ/d ME for each additional piglet at farrowing.

Total ME requirement of sows in thermoneutral conditions increased with increasing parity (30.6, 33.3, 34.0 MJ/d for parity 1, 2 and 3+, respectively) and with litter size (32.4, 33.3 and 34.0 MJ/d for S, M and L litters, respectively, Table 5). On average, 76\% of the total ME was required for sow's maintenance, $6 \%$ for conceptus, and $18 \%$ for maternal reserves. This distribution of ME among the different functions differed according to gestation weeks (Fig. 4) and parity. The ME requirement for maintenance increased with parity (on average 22.4, 24.9 and $28.0 \mathrm{MJ} / \mathrm{d}$ respectively for parity 1, 2 and 3+) and again slightly with LS (on average 24.7, 25.0, and 25.6 MJ/d for S, M and L, respectively). The ME requirement for conceptus increased during gestation (by about $6 \mathrm{MJ} / \mathrm{d}$ from week 1 to 17), with increasing LS (on average $1.03,1.58$ and $2.05 \mathrm{MJ} / \mathrm{d}$ for S, M, L litters, respectively) and was higher for parity 2 (1.63 MJ/d) compared with parity 1 and $3+$ sows (1.46 and $1.55 \mathrm{MJ} / \mathrm{d}$, respectively). The ME requirement for sow body reserves was higher for parity $2(7.04 \mathrm{MJ} / \mathrm{d})$ compared with parity 1 and 3+ sows (6.73 and 5.96 MJ/d, respectively), and for sows having M litters (6.77 MJ/d) compared with sows having S and L litters (6.66 and 6.31 MJ/d). The amount of ME 
remaining for maternal body reserves decreased during gestation, by about $-7 \mathrm{MJ} / \mathrm{d}$ on average between week 1 and 17. Consequently, the average feed allowance needed to meet ME requirement increased with parity $(2.39,2.61$ and $2.78 \mathrm{~kg} / \mathrm{d}$ for parity 1,2 and $3+$, respectively, for a diet containing $13 \mathrm{MJ} \mathrm{ME} / \mathrm{kg}$ ).

When ambient temperature decreased below LCT, daily ME requirement increased by 0.49 $\mathrm{MJ} / \mathrm{d}$ per degree, which corresponds to a total increase of $1.96 \pm 0.18 \mathrm{MJ} / \mathrm{d}$ at $12^{\circ} \mathrm{C}$. This corresponded to an increase in daily feed requirement of about $150 \mathrm{~g} / \mathrm{d}$ (i.e. $2.84 \pm 0.04 \mathrm{~kg}$ at $12^{\circ} \mathrm{C}$ versus $2.69 \pm 0.04 \mathrm{~kg}$ at $16^{\circ} \mathrm{C}$, Table 7$)$. It may be noted that this effect was more marked at the end of the gestation period.

\section{SID lysine requirement}

During gestation, AA requirements slightly increased over the first 6 weeks, then plateaued until week 10, and increased again, more steeply this time, until the end of gestation period (Fig. 5). Variability increased after week 10 compared with the beginning of the gestation period. Until week 10, between 2.2 and $3.0 \mathrm{~g}$ SID Lys per $\mathrm{kg}$ of feed met the requirement of $75 \%$ of the sows, and $50 \%$ of sow AA requirements were satisfied with SID Lys between 2.0 and $2.7 \mathrm{~g} / \mathrm{kg}$. Between week 10 and the end of the gestation period SID Lys required to achieve the requirements of $75 \%$ of sows increased from 3.0 to $5.4 \mathrm{~g}$ SID Lys per $\mathrm{kg}$ of feed, the corresponding values to achieve the requirements of $50 \%$ of sows were 2.7 and $4.9 \mathrm{~g} / \mathrm{kg}$, respectively.

The variation in daily AA requirements during gestation increased with parity (on average $+4.69,+5.18,+5.66 \mathrm{~g}$ of SID Lys /d for parity 1,2 , and $3+$, respectively, when passing from 30 to $110 \mathrm{~d}$ of gestation) and LS (on average $+3.71,+5.28,+7.14 \mathrm{~g}$ of SID Lys $/ \mathrm{d}$ for L, M and L litters, respectively). Overall, SID AA requirement per $\mathrm{kg}$ feed increased with LS (SID 
Lys: 3.00, 3.27, $3.50 \mathrm{~g} / \mathrm{kg}$ for S, M, L litters, respectively, $P<0.01$, Table 6) and decreased when parity increased (SID Lys: 3.61, 3.17, $2.84 \mathrm{~g} / \mathrm{kg}$ for parity 1,2 and $3+$, respectively, $P<$ 0.01 , Table 6).

Changes in other AA requirements per day and per $\mathrm{kg}$ of feed according to parity, litter size and gestation weeks were similar to those observed for SID Lys, due to the rather low variability in the profile of AA requirements (Table 6). The ratio of SID AA requirements per $100 \mathrm{~g}$ SID Lys requirement (mean $\pm \mathrm{SD}$ ) was $27.1 \pm 0.57 \mathrm{~g} / 100 \mathrm{~g}$ for methionine, $66.4 \pm 1.27$ $\mathrm{g} / 100 \mathrm{~g}$ for methionine and cysteine, $21.2 \pm 0.36 \mathrm{~g} / 100 \mathrm{~g}$ for tryptophan, $74.0 \pm 1.38 \mathrm{~g} / 100 \mathrm{~g}$ for threonine, $61.5 \pm 1.13 \mathrm{~g} / 100 \mathrm{~g}$ for phenylalanine, $102.0 \pm 1.88 \mathrm{~g} / 100 \mathrm{~g}$ for phenylalanine and tyrosine, $102.6 \pm 1.87 \mathrm{~g} / 100 \mathrm{~g}$ for leucine, $64.8 \pm 1.30 \mathrm{~g} / 100 \mathrm{~g}$ for isoleucine, $78.6 \pm 1.39$ $\mathrm{g} / 100 \mathrm{~g}$ for valine, $32.6 \pm 0.60 \mathrm{~g} / 100 \mathrm{~g}$ for histidine and $42.9 \pm 0.84 \mathrm{~g} / 100 \mathrm{~g}$ for arginine. These ratios were only slightly, yet significantly, affected by LS and parity as illustrated in Table 6 for Thr/Lys ratio.

When the ambient temperature decreased below $16^{\circ} \mathrm{C}$, the SID AA requirement remained relatively constant per day but decreased per $\mathrm{kg}$ of feed. For SID Lys the decrease was 0.04 $\mathrm{g} / \mathrm{kg}$ per ${ }^{\circ} \mathrm{C}$ below LCT, the effect of temperature being more marked towards the end of the gestation period (Table 7).

\section{STTD-P and Total Ca requirements}

Total-Ca and STTD-P requirements were low and relatively steady over the first 9 weeks of gestation and markedly increased thereafter (Fig. 6). Variability increased after week 10 compared with the beginning of the gestation period. Until week 10, around 1.0 g STTD-P per $\mathrm{kg}$ of feed satisfied the phosphorus requirement of the sows with almost no variability week by week. After week 10 and until the end of the gestation period, between 1.2 and $2.6 \mathrm{~g}$ STTD-P per kg of feed satisfied the phosphorus requirements of $75 \%$ of the sows depending 
on the week, and $50 \%$ of sow phosphorus requirements were satisfied with STTD-P between 1.1 and $2.3 \mathrm{~g} / \mathrm{kg}$.

The extent of the increase in requirement by the end of gestation increased with parity (on average $+2.35,+2.73,+3.21 \mathrm{~g} / \mathrm{d}$ of STTD-P between 30 and $110 \mathrm{~d}$ of gestation for parity 1,2 and $3+$, respectively) and litter size (on average $+1.60,+2.98,+4.49 \mathrm{~g} / \mathrm{d}$ of STTD-P between 30 and $110 \mathrm{~d}$ of gestation for S, M and L litters, respectively).

The average STTD-P requirement in g/d increased with increasing LS (Table 5) and increasing parity (on average $3.23,3.53,3.63 \pm 0.18 \mathrm{~g} / \mathrm{d}$ for parity 1,2 and $3+$, respectively) while STTD-P requirement in $\mathrm{g} / \mathrm{kg}$ remained rather constant with increasing parity (on average $1.36,1.35,1.35 \pm 0.07 \mathrm{~g} / \mathrm{kg}$ for parity 1,2 and $3+$, respectively). STTD-P requirements for maintenance, growth and conceptus increased with parity and LS except for maternal growth where they decreased with increasing parity (on average $0.79,0.76$, and 0.67 $\pm 0.05 \mathrm{~g} / \mathrm{d}$ for parity 1,2 and $3+)$.

Total-Ca requirement and $\mathrm{Ca}$ requirements for maintenance, maternal growth and conceptus increased with LS. Total-Ca requirement (in $\mathrm{g} / \mathrm{d}$ ) and Ca requirement for maintenance increased with parity, while Total-Ca requirement (in $\mathrm{g} / \mathrm{kg}$ ) and Ca requirement for maternal growth decreased. Ca requirement for conceptus was higher for parity 2 sows compared to parity $3+$ sows; both with higher requirement than parity 1 sows $(1.90,2.12$ and $2.01 \pm 0.31$ $\mathrm{g} / \mathrm{d}$ respectively for parity 1,2 and $3+)$.

The Total-Ca/ STTD-P ratio varied between 2.86 and 3.30, with an average of 3.10. This ratio was similar for S and M litters of parity 1 and 2 sows. Moreover, the Total-Ca/STTD-P ratio increased with LS, decreased with parity, and increased during gestation, from around 3.05 from week 0 to 9 up to 3.20 on average at week 17.

As for AA requirements, Total-Ca, and STTD-P requirements per kg feed decreased with decreasing temperature $(P<0.01)$, respectively by 0.05 , and $0.02 \mathrm{~g} / \mathrm{kg}$ per ${ }^{\circ} \mathrm{C}$ below $\mathrm{LCT}$, on 
average throughout the entire gestation period. This decrease was more pronounced at the end of the gestation period (Table 7).

\section{DISCUSSION}

\section{General Structure of the Model}

The modeling approach is based on a combination of current knowledge of nutrient use of gestating sows with the flow of data produced on-farm, in a similar way to the work performed by Gauthier et al. (2019) for lactating sows. The approach considers individual variability in nutrient requirement according to gestation stage, sow characteristics at mating (age, parity, body condition) and reproductive performance (number and weight of piglet at farrowing). This approach makes it possible to calculate farm specific nutrient recommendations based on their own flow of data.

In the present study, measured individual data were used to obtain LS and piglets birth BW. However, when applying the model in real-time, LS and piglet birth BW will not be available since techniques such as the ultrasound counting of foetuses are not applicable in practice. The alternative will be the development of within-farm predictive models or using datamining approaches, based on the different criteria that are known to affect prolificacy, such as parity and sow age, prolificacy in previous litters, the duration of the interval between weaning and fertilization, and to a lesser extent the duration of previous lactation. For the future, the use of genomics (Fangmann et al., 2017) might also be an interesting perspective.

\section{Variation in energy requirement}

Energy requirement varied throughout gestation, with parity and among the different compartments (maintenance, conceptus, maternal lipids and maternal proteins), which is in accordance with the results of Thomas et al. (2018). The energy requirement for maintenance 
was the highest throughout gestation. In early and mid-gestation, energy is used primarily to support maintenance and maternal growth, while from around 70 days of gestation the metabolic focus shifts to the growing demands for the conceptus (McPherson et al., 2004)(Fig.4). The fact that energy for protein retention is greater in parity 1 than parity 2 or $3+$ sows is mainly due to the higher protein retention potential of these animals that are still growing, and their lower energy requirement for maintenance is due to their lower BW (Dourmad et al., 1999). Pregnant sows are fed restrictively to control their body condition and the risk of reproductive troubles due to insufficient or excessive body fatness (Dourmad, 1994). Therefore, energy allowance during gestation is mainly affected by sow body condition and age or parity at insemination, which accounts for the greatest part of the variability among sows. This is in line with usual practices, at least in some farms, when energy supply is modulated according to parity, body condition (Young et al., 2004) and gestation stage, considering two (NRC, 2012; Cloutier et al., 2019) or three phases (Clowes et al., 2003), with an increased feed supply in late gestation, and sometimes a decrease in mid gestation. Indeed, when introducing phase feeding, it is necessary to reduce feed intake in early- and/or mid- gestation to accommodate an increase in feed allowance in late gestation (Moehn et al., 2011). Increasing energy allowance in late gestation may improve piglets' vitality and survival at birth, especially in hyperprolific sows Quiniou et al. (2005), and helps maintaining sows' body reserves at parturition, whist reducing backfat loss during lactation (Miller et al. 2000). Moreover, Shelton et al. (2009) found that additional feed allowance in late gestation increased the conception rate after weaning. The present model would allow going further, up to an individual adaptation of energy supply considering individual BW and BT at insemination and even when available their evolution along gestation. 


\section{Variation in Total-Ca and STTD-P requirements}

During the first two thirds of the gestation period, Total-Ca and STTD-P requirements were low and corresponded to the requirements for maintenance and maternal growth, while during the final third of the gestation period the requirements for these minerals increased, due to the faster growth of the foetuses, and were largely affected by LS. These results are in accordance with previous studies (Jondreville and Dourmad, 2005; NRC, 2012). They show the possibility of a reduction in phosphorus and calcium supplies in early gestation, but this reduction has to be implemented carefully since in our model we do not yet consider the possible requirement for the restoration of body minerals that may have been mobilized during the previous lactation. In the present study, the Total-Ca/ STTD-P ratio (on average of 3.10 , and 3.13 and 3.07 in parity 1 and parity $3+$, respectively) is slightly lower than the ratio proposed by Jongbloed et al. (2003) (3.3 in parity 1 to 3 sows and 3.5 in higher parities) but close to the ratio calculated by Bikker and Blok 2017 (3.15 in primiparous and 2.9 in multiparous sows). In agreement with the results of Bikker et al. (2017), the Total-Ca/ STTD$\mathrm{P}$ ratio increased during gestation because of a higher Total-Ca/ STTD-P ratio in piglets (from 3.15 to 3.30 in parity 1 and from 2.8 to 3.2 in parity 5$)$.

\section{Variation in AA requirements}

The increase in AA requirements in late gestation is in accordance with previous studies (Kim et al., 2009; Levesque et al., 2011) and is due to a change in the demand for nutrients from maternal lean tissue growth in early gestation to foetal and mammary growth in late gestation (McPherson et al., 2004). This important variation suggests the importance of adjusting diet AA content during gestation, at least with the use of a different diet in the final third of the gestation period, instead of feeding a fixed amount of AA throughout the entire gestation period. Indeed, in the case of a diet with a fixed AA content, the sows will be overfed in early 
gestation, which will increase feed costs and potential environmental impacts due to the excretion of excess nitrogen (Adeola, 1999), while they will be underfed in late gestation leading to the possible breakdown of maternal protein tissues to support foetal growth and/or in the case of more severe deficiency to reduced piglets birth weight (McPherson et al., 2004), especially in the case of hyper-prolific sows. In this context it may thus be relevant to consider combining a change of feeding level and of feed AA composition in late gestation (Goncalves et al., 2016).

\section{Toward a better adjustment of $A A$ and $P$ supplies}

In practice, a first step to consider the large variability in AA and $\mathrm{P}$ requirements between sows and according to gestation stage is to group sows based on parity and gestation stage. With cumulative distribution plots (Fig. 7) we can propose different diets based on parity and gestation periods (P1: week 1 to 11 ; P2: week 12 to 17 ) to feed up to $90 \%$ of the sows according to their requirements. When grouping the sows by parity and gestation period, the concentrations of SID Lys needed to satisfy the requirements of $90 \%$ of the sows were of 2.8 , $3.4,4.5$, and $5.0 \mathrm{~g} / \mathrm{kg}$ for the multiparous in $\mathrm{P} 1$, the primiparous in $\mathrm{P} 1$, the multiparous in the $\mathrm{P} 2$ and the primiparous in P2 respectively, while the concentrations of STTD-P were of 1.1, 2.2 and $3.3 \mathrm{~g} / \mathrm{kg}$ for all the sows in $\mathrm{P} 1$, the multiparous in $\mathrm{P} 2$ and the primiparous in $\mathrm{P} 2$. In Fig. 8 we compared the SID lysine requirements obtained in the present study with those derived from different recommendations. In general, variability is greater for the late gestation period (P2) compared to the first part of gestation (P1). The NRC (2012) requirements of SID lysine per $\mathrm{kg}$ of feed are the highest and above those of the present study. They meet the requirements of all the primiparous sows and of the $99^{\text {th }}$ percentile for multiparous sows, both in P1 and P2. Danish recommendations, which do not differ according to parity (Tybirk et al., 2015 ), meet the requirements of the $95^{\text {th }}, 26^{\text {th }}, 100^{\text {nd }}$ and $74^{\text {th }}$ percentile for primiparous $\mathrm{P} 1$, 
primiparous $\mathrm{P} 2$, multiparous $\mathrm{P} 1$ and multiparous $\mathrm{P} 2$, respectively. The requirements calculated from InraPorc ${ }^{\circledR}$ (Dourmad et al., 2008) meet the requirements of the $100^{\text {th }}, 98^{\text {th }}$, $82^{\text {nd }}$ and $88^{\text {th }}$ percentile for primiparous $\mathrm{P} 1$, primiparous $\mathrm{P} 2$, multiparous $\mathrm{P} 1$ and multiparous $\mathrm{P} 2$, respectively. They are the closest to our recommendations to feed $90 \%$ of the sows up to their requirements. Differences between recommendations are mainly explained by differences in assumptions for SID lysine efficiency or in the definition of early and late gestation. For instance, in the present study late gestation period starts earlier ( $77 \mathrm{~d})$ than considered for the other recommendations (i.e., 90, 100 and $108 \mathrm{~d}$ for NRC, InraPorc $\AA$, and the Danish study, respectively) which may account for the higher values in late gestation, as AA requirements increase with gestation days. As regard to Lys efficiency, in NRC (2012) efficiency of SID lysine for pregnancy is 0.47 , representing an adjustment to the reference value of 0.75 to account for between animal variations in order to provide a population requirement. In the same way InraPorc ${ }^{\circledR}$ uses a slightly lower efficiency than in the present study (i.e. 0.65 vs 0.72 ) but not low enough to take account of between animal variations, especially in multiparous sows.

These results underline the need for different diets that vary in AA and mineral composition, according to gestation stage and parity, showing the interest of a multiphase feeding strategy which could easily be set up in practice by grouping the sows according to their parity and gestation stage (early, late) and moving them to the feed line that carries the appropriate ration.

Nevertheless, looking at the huge variability among sows of the same parity group (Fig.5) this phase feeding strategy adapted to each parity would only constitute a first step towards precision feeding. Therefore, the next step will be to allow the mixing of two diets with different nutrient levels (high and low) and daily feed allowances, as it has been done for fattening pigs (Pomar et al., 2009; Andretta et al., 2016). From a feed cost point of view this strategy would also be 
preferable compared to the multiphase strategy regarding parity, but it would require adapted feeding equipment (Moehn et al., 2011).

Moving forward to a daily individual feeding system using smart feeding and housing equipment could also take benefit of some others factors affecting nutrient requirement, already implemented in the model. For example, the ambient temperature and the activity of each sow could be recorded daily and included in the requirement calculations. Indeed, there is an increase of 10 to $18 \mathrm{~kJ} \mathrm{ME} / \mathrm{kg} \mathrm{BW}^{-0.75}$ per day and per degree Celsius below the LCT and of $0.30 \mathrm{~kJ} \mathrm{ME} / \mathrm{kg} \mathrm{BW}^{-0.75} / \mathrm{d} / \mathrm{min}$ standing (currently fixed at $4 \mathrm{~h}$ standing) which almost doubles the instantaneous heat production during standing when compared to lying down (Dourmad et al., 2008). In the context of climate change the effect of heat stress could also be interesting to consider in the future, although gestating sows are less sensitive to high temperature than lactating sows (Williams et al., 2013). However, this will require some improvements in the model which do consider yet the effects of temperature above the thermoneutral zone. Moreover, as shown by Wegner et al. (2016) the use of a temperature-humidity index (THI) would be more appropriate than temperature alone. For the future, it might also be interesting to modulate the objectives of BW after farrowing according to a specific trajectory for each individual sow, based on their own measured evolution of BW and BT.

All these adjustments will require the farms to be equipped with devices and sensors (weighing scales, cameras, accelerometers, hydro-thermometers, etc.) that continuously record this information to feed real-time databases. It will also require building, based on the present model, a full decision support system that may be embedded in automated feeding equipment. As indicated by Gauthier et al. (2019) the approach developed in the present study is a contribution to the development of a new type of models that would be "data ready" and "precision-feeding ready", and able to process both historical farm data (e.g. for ex post assessment of nutrient requirements) and real-time data (e.g. to control precision feeding). 


\section{CONCLUSION}

Nutrient requirement is highly variable among sows and throughout gestation. Better considering the high variability of sows' requirement in practice should thus make it possible to optimize their performance whilst reducing feeding cost. To start with, it can be achieved by grouping and feeding sows according to gestation week and parity. The model of the present study can be used to predict the individual nutrient requirement of sows during gestation and underlines the importance of data recorded on farm in real-time. It also provides an initial step in the development of a decision support system that may be embedded in automated feeding equipment. 


\section{LITERATURE CITED}

Adeola, O. 1999. Nutrient management procedures to enhance environmental conditions: An introduction. J. Anim. Sci. 77:427-429.

Andretta, I., C. Pomar, M. Kipper, L. Hauschild, and J. Rivest. 2016. Feeding behavior of growing-finishing pigs reared under precision feeding strategies. J. Anim. Sci. 94:3042-3050.

Bikker, P., and M. C. Blok. 2017. Phosphorus and calcium requirements of growing pigs and sows, Wageningen Livestock Research, Wageningen.

Cloutier, L., C. Pomar, M. P. L. Montminy, J. F. Bernier, and J. Pomar. 2015. Evaluation of a method estimating real-time individual lysine requirements in two lines of growingfinishing pigs. Animal. 9:561-568

Clowes, E. J., R. Kirkwood, A. Cegielski, and F. X. Aherne. 2003. Phase-feeding protein to gestating sows over three parities reduced nitrogen excretion without affecting sow performance. Livest. Prod. Sci. 81:235-246.

Dourmad, J. Y., M. Etienne, A. Valancogne, S. Dubois, J. van Milgen, and J. Noblet. 2008. InraPorc: A model and decision support tool for the nutrition of sows. Anim. Feed Sci. Tech. 143:372-386.

Dourmad, J.Y., and M. Étienne. 2002. Dietary lysine and threonine requirements of the pregnant sow estimated by nitrogen balance. J. Anim. Sci., 80:2144-2150.

Dourmad J.Y., M. Etienne, A. Prunier A., and J. Noblet 1994. The effect of energy and protein intake of sows on their longevity. Livest. Prod. Sci., 40, 87-97

Dourmad, J. Y., J. Noblet, M. C. Père, and M. Etienne. 1999. Mating, pregnancy and pre-natal growth. In: Kyriazakis, I. (Ed), A quantitative Biology of the Pig, CAB, pp. 129-153

Fangmann, A., R. A. Sharifi, J. Heinkel, K. Danowski, H. Schrade, M. Erbe, and H. Simianer. 2017. Empirical comparison between different methods for genomic prediction of 
number of piglets born alive in moderate sized breeding populations. J. Anim. Sci. 95:1434-1443.

Gauthier, R., C. Largouet, C. Gaillard, L. Cloutier, F. Guay, and J. Y. Dourmad. 2019. Dynamic modeling of nutrient use and individual requirements of lactating sows. J. Anim. Sci. 97:2822-2836.

Goncalves, M. A. D., K. M. Gourley, S. S. Dritz, M. D. Tokach, N. M. Bello, J. M. DeRouchey, J. C. Woodworth, and R. D. Goodband. 2016. Effects of amino acids and energy intake during late gestation of high-performing gilts and sows on litter and reproductive performance under commercial conditions. J. Anim. Sci. 94:1993-2003

Jondreville, C., and J. Y. Dourmad. 2005. Le phosphore dans la nutrition des porcs. INRA Prod. Anim. 18:183-192.

Jongbloed, A. W., J. T. M. Diepen, and K. van, P.A. 2003. Fosfornormen voor varkens: herziening 2003. CVB-documentatierapport nr. 30.

Kim, S. W., W. L. Hurley, G. Wu, and F. Ji. 2009. Ideal amino acid balance for sows during gestation and lactation. J. Anim. Sci. 87:E123-132.

King, R.H. and W.G. Brown. 1993. Interrelationships between dietary protein level, energy intake, and nitrogen retention in pregnant gilts. J. Anim. Sci. 71:2450-2456.

Laird, N. M., and J. H. Ware. 1982. Random-Effects Models for Longitudinal Data. Biometrics. 38:963-974.

Levesque, C. L., S. Moehn, P. B. Pencharz, and R. O. Ball. 2011. The threonine requirement of sows increases in late gestation. J. Anim. Sci. 89:93-102.

McPherson, R. L., F. Ji, G. Wu, J.R. Blanton, Jr., and S. W. Kim. 2004. Growth and compositional changes of fetal tissues in pigs. J. Anim. Sci. 82:2534-2540. 
Moehn, S., D. Franco, C. Levesque, R. Samuel, and R. O. Ball. 2011. New energy and amino acid requirements for gestating sows. Advances in Pork Production, Volume 22, pg. 10ième WCGALP, abstract 123, Vancouver, Canada, 17-22 août 2014

Miller, H.M., G.R. Foxcroft and F.X. Aherne. 2000. Increasing food intake in late gestation improved sow condition throughout lactation but did not affect piglet viability or growth rate. Anim. Sci. 71:141-148.

Moughan, P. 1999. Protein metabolism in the growing pig/ In: I. Kyriazakis, editor. A quantitative biology of the pig. CABI Publishing, Wallingford, UK. P. 299-332

Noblet, J., Y. Henry, and S. Dubois. 1987. Effect of Protein and Lysine Levels in the Diet on Body Gain Composition and Energy Utilization in Growing Pigs. J. Anim. Sci. Biotech. 65:717-726.

Noblet, J., B. Sève, and C. Jondreville. 2004. Valeurs nutritives pour les porcs. In: D. Sauvant, J.M. Perez, and G. Tran, editors. Tables of composition and nutritional value of feed materials, Wageningen Academic Publishers, The Netherlands. P. 22-35

NRC. 2012. Nutrient Requirements of Swine: Eleventh Revised Edition. The National Academies Press, Washington, DC.

Pinheiro, J., D. Bates, S. DebRoy, D. Sarkar, and R. C. Team. 2018. NLME: Linear and Nonlinear Mixed Effects Models. R package version 3.1-137, https://CRAN.Rproject.org/package $=$ nlme

Pinheiro, J. C., and D. M. Bates. 2000. Mixed-Effects Models in S and S-PLUS Springer, esp. pp. $235,397$.

Pomar, C., L. Hauschild, G. H. Zhang, J. Pomar, and P. A. Lovatto. 2009. Applying precision feeding techniques in growing-finishing pig operations. Rev. Bras. Zootecn. 38:226237. 
Quiniou, N. 2005. Influence de la quantité d'aliment allouée à la truie en fin de gestation sur le déroulement de la mise bas, la vitalité des porcelets et les performances de lactation. Journ. Rech. Porcine, 37, 187-194.

Sauvant, D., J.M. Perez, and G. Tran. 2004. Tables of composition and nutritional value of feed materials. Wageningen Academic Publishers, The Netherlands

Shelton, N. W., J. M. DeRouchey, C. R. Neill, M. D. Tokach, S. S. Dritz, R. D. Goodband and J. L. Nelssen. 2009. Effects of increasing feeding level during late gestation on sow and litter performance. Kansas State University. Swine Day 2009. Report of Progress 1020

Thomas, L. L., R. D. Goodband, M. D. Tokach, S. S. Dritz, J. C. Woodworth, and J. M. DeRouchey. 2018. Partitioning components of maternal growth to determine efficiency of feed use in gestating sows. J. Anim. Sci. 96:4313-4326.

Tybirk, P. 2015. Nutrient recommendations for pigs in Denmark. SEGES Pig Research Centre, Copenhagen, Denmark. Available at: http://www.pigresearchcentre.dk/ /media/Files/PDF\%20\%20UK/Nutrient\%20recommendations\%20UK.pdf

Van Milgen, J., J. Noblet, A. Valancogne, S. Dubois, J.Y. Dourmad. 2008. InraPorc: a model and decision support tool for the nutrition of growing pigs. Anim. Feed Sci. Tech. $143: 387-405$.

Walker, B., and B. A. Young. 1992. Modeling the development of uterine components and sow body composition in response to nutrient intake during pregnancy. Livest. Prod. Sci. 30:251-264.

Wegner, K., C. Lambertz, G. Das, G. Reiner, and M. Gauly. 2016. Effects of temperature and temperature-humidity index on the reproductive performance of sows during summer months under a temperate climate. Anim. Sci. J. 87:1334-1339. 
Williams A. M., T. J. Safranski, D. E. Spiers, P. A. Eichen, E. A. Coate, and M. C. Lucy. 2013. Effects of a controlled heat stress during late gestation, lactation, and after weaning on thermoregulation, metabolism, and reproduction of primiparous sows. J. Anim. Sci., 91:2700-2714.

Young, M. G., M. D. Tokach, F. X. Aherne, R. G. Main, S. S. Dritz, R. D. Goodband, and J. L. Nelssen. 2004. Comparison of three methods of feeding sows in gestation and the subsequent effects on lactation performance. J. Anim. Sci., 82:3058-3070. 
Figure 1. Estimate of individual nutrient requirement from data collected on-farm.

Figure 2. Structure of the Python model used to run the simulations.

Figure 3. Average metabolizable energy requirement of sows as influenced by their body weight at insemination. Each ellipse represents a population of sows from the same parity category $(1,2$ or $3+)$

Figure 4. Stacked area chart of the metabolizable energy requirement partitioned between body reserves, conceptus and maintenance over gestation weeks of group-housed sows at $16^{\circ} \mathrm{C}$ in thermoneutral conditions.

Figure 5. Boxplots of SID Lysine requirement (in $\mathrm{g} / \mathrm{kg}$ ) of sows for each gestation week receiving on average over the gestation $2.60 \mathrm{~kg}$ of feed per day of a diet containing $13 \mathrm{MJ}$ $\mathrm{ME} / \mathrm{kg}$

Figure 6. Boxplots of STTD Phosphorus requirement (in $\mathrm{g} / \mathrm{kg}$ ) of sows for each gestation week receiving on average over the gestation $2.60 \mathrm{~kg}$ of feed per day of a diet containing 13 $\mathrm{MJ} \mathrm{ME} / \mathrm{kg}$

Figure 7. Cumulative distribution of the SID lysine requirement per $\mathrm{kg}$ of feed (a) and the digestible phosphorus requirement per $\mathrm{kg}$ of feed (b) according to group (multiparous in P1, multiparous in $\mathrm{P} 2$, primiparous in $\mathrm{P} 1$, primiparous in $\mathrm{P} 2$ with $\mathrm{P} 1$ being the period from week 0 to 11 , and $\mathrm{P} 2$ from week 12 to 17). These plots can be used to determine the concentrations of SID lysine and digestible phosphorus (STTD-P) needed to satisfy the requirements of 90\% of the sows (vertical dotted lines).

Figure 8. Boxplots of SID lysine requirement per $\mathrm{kg}$ of feed in gestating sows according to parity and period (early gestation period: P1 - and late gestation period: P2 -, with a day of diet change varying between 77 and 108 depending on the reference). Calculated requirements are compared to recommendations of Dourmad et al. (2008, green dots), NRC (2012, blue dots), Tybirk et al. (2015, red dots) and those of the present study to meet the requirements of $90 \%$ of the sows (black dots). 
Table 1. Main equations describing energy and protein utilization by gestating sows (adapted from Dourmad et al., 2008)

\begin{tabular}{|c|c|c|}
\hline Energ & $\begin{array}{ll}\mathrm{ME}=\mathrm{ME}_{\mathrm{m}}+\mathrm{ER}_{\mathrm{c}} / \mathrm{k}_{\mathrm{c}}+\mathrm{ER}_{\mathrm{m}} / \mathrm{k}_{\mathrm{m}} \\
\mathrm{ME}=\mathrm{ME}_{\mathrm{m}}+\mathrm{ER}_{\mathrm{c}} / \mathrm{k}_{\mathrm{c}}+\mathrm{ER}_{\mathrm{mp}} / \mathrm{k}_{\mathrm{p}}+\mathrm{ER}_{\mathrm{ml}} / \mathrm{k}_{\mathrm{l}}\left(-\mathrm{ER}_{\mathrm{ml}} / \mathrm{k}_{\mathrm{r}} \times \mathrm{k}_{\mathrm{r}}\right) \\
\mathrm{ME}_{\mathrm{m}}: & \mathrm{ME} \text { for maintenance } \\
E R_{\mathrm{c}}: & \text { energy retention in conceptus } \\
E R_{\mathrm{ml}}: & \text { energy retained in maternal lipids } \\
E R_{\mathrm{mp}}: & \text { energy retained in maternal protein } \\
\mathrm{k}_{\mathrm{c}}=0.50 & \text { efficiency of ME retention in conceptus } \\
\mathrm{k}_{\mathrm{p}}=0.60 & \text { efficiency of ME retention in maternal protein } \\
\mathrm{k}_{\mathrm{l}}=0.80 & \text { efficiency of ME retention in maternal lipids } \\
\mathrm{k}_{\mathrm{m}}=0.77 & \text { average efficiency of ME retention in maternal tissues } \\
\mathrm{k}_{\mathrm{r}}=0.80 & \text { efficiency of energy utilization from maternal reserves }\end{array}$ & $\begin{array}{l}{[1 \mathrm{a}]} \\
{[1 \mathrm{~b}]}\end{array}$ \\
\hline $\begin{array}{l}\text { ME for maintenance } \\
\text { and effect of activity } \\
\text { and ambient } \\
\text { temperature }\end{array}$ & $\begin{array}{l}\text { in thermoneutral conditions } \\
\mathrm{ME}_{\mathrm{m}}=440 \mathrm{~kJ} \cdot \mathrm{BW}^{-0.75} \cdot \mathrm{d}^{-1} \text { (for } 240 \mathrm{~min}^{-1} \mathrm{~d}^{-1} \text { standing activity) } \\
\text { physical activity }=0.30 \mathrm{KJ} \cdot \mathrm{kg} \mathrm{BW}^{-0,75} \cdot \mathrm{d}^{-1} \cdot \mathrm{min}^{-1} \text { standing } \\
\text { below lower critical temperature }(\mathrm{LCT}) \\
\text { In individually housed sows }: \mathrm{LCT}=20^{\circ} \mathrm{C} \\
\mathrm{ME}_{\mathrm{m}} \text { increases by } 18 \mathrm{~kJ} \cdot \mathrm{kg} \mathrm{BW}-0.75 \cdot \mathrm{d}^{-1} \cdot{ }^{\circ} \mathrm{C}^{-1} \\
\text { In group-housed sows : } \mathrm{LCT}=16^{\circ} \mathrm{C} \\
\mathrm{ME}_{\mathrm{m}} \text { increases by } 10 \mathrm{~kJ} \cdot \mathrm{kg} \mathrm{BW} \mathrm{BW}^{-0.75} \cdot \mathrm{d}^{-1} \cdot{ }^{\circ} \mathrm{C}^{-1}\end{array}$ & $\begin{array}{l}{[2]} \\
{[3]}\end{array}$ \\
\hline Ener & $\begin{array}{l}\mathrm{ERc}(\mathrm{t}): \text { Total energy in conceptus }(\mathrm{kJ}) \text { on day } \mathrm{t} \\
\mathrm{ERc}(\mathrm{t})=\exp \left(11.72-8.62 \mathrm{e}^{-0,0138 \mathrm{t}}+0.0932 \mathrm{Litter} \text { size }\right) \\
\mathrm{ER}_{\mathrm{mp}}: \text { Energy in maternal tissues as protein }(\mathrm{MJ}) \\
\mathrm{ER}_{\mathrm{mp}}(\mathrm{t})=23.8 \times 6.25 \times \mathrm{NRm}(\mathrm{t}) \\
\mathrm{ER}_{\mathrm{ml}}: \text { energy in maternal tissues as lipids }(\mathrm{MJ}) \\
\text { Energy balance }>0 \\
\quad \mathrm{ER}_{\mathrm{ml}}(\mathrm{t})=\left(\mathrm{ME}-\left(\mathrm{ME}_{\mathrm{m}}+\mathrm{ER}_{\mathrm{c}} / \mathrm{k}_{\mathrm{c}}+\mathrm{ER}_{\mathrm{mp}} / \mathrm{k}_{\mathrm{p}}\right)\right) \times \mathrm{k}_{\mathrm{l}} \\
\text { Energy balance }<0 \\
\quad \mathrm{ER}_{\mathrm{ml}}(\mathrm{t})=\left(\mathrm{ME}-\left(\mathrm{ME}_{\mathrm{m}}+\mathrm{ER}_{\mathrm{c}} / \mathrm{k}_{\mathrm{c}}+\mathrm{ER}_{\mathrm{mp}} / \mathrm{k}_{\mathrm{p}}\right)\right) / \mathrm{k}_{\mathrm{r}}\end{array}$ & [8b] \\
\hline & $\begin{array}{ll}\mathrm{NR}_{\mathrm{c}}: & \text { Total } \mathrm{N} \text { content in conceptus }(\mathrm{g}) \\
& \mathrm{NR}_{\mathrm{c}}(\mathrm{t})=\exp \left(8.090-8.71 \mathrm{e}^{-0,0149 \mathrm{t}}+0.0872 \text { Litter size }\right) / 6.25 \\
\mathrm{NR}: & \text { Total } \mathrm{N} \text { retention }\left({\left.\mathrm{g} . \mathrm{d}^{-1}\right)}\right. \\
\mathrm{NR}(\mathrm{t})=0.85\left(\mathrm{~d}\left(\mathrm{NR}_{\mathrm{c}}\right) / \mathrm{dt}-0.4+45.9(\mathrm{t} / 100)-105.3(\mathrm{t} / 100)^{2}+\right. \\
\left.\quad 64.4(\mathrm{t} / 100)^{3}\right)+\mathrm{a}\left(\mathrm{ME}-\mathrm{ME}_{\mathrm{mm}}\right) \\
\\
\text { where } \mathrm{a}=\mathrm{f}(\mathrm{BW} \text { at mating }) \text { and } \mathrm{ME} \mathrm{mm}_{\mathrm{m}}=\mathrm{ME}_{\mathrm{m}} \text { at mating } \\
\mathrm{NR}_{\mathrm{m}}: \mathrm{N} \text { retention in maternal tissues }(\mathrm{MJ}) \\
\mathrm{NR}_{\mathrm{m}}(\mathrm{t})=\mathrm{NR}(\mathrm{t})-\mathrm{NR}_{\mathrm{c}}(\mathrm{t})\end{array}$ & [10] \\
\hline $\begin{array}{l}\text { Maternal protein and } \\
\text { lipid deposition }\end{array}$ & $\begin{array}{l}\mathrm{PR}_{\mathrm{m}}(\mathrm{t}): \text { maternal protein retention in tissues }(\mathrm{g} / \mathrm{d}) \\
\quad \mathrm{PR}_{\mathrm{m}}(\mathrm{t})=\mathrm{NRm}(\mathrm{t}) \times 6.25 \\
\mathrm{LI}_{\mathrm{m}}(\mathrm{t}): \text { maternal lipid retention }(\mathrm{g} / \mathrm{d}) \\
\mathrm{LI}_{\mathrm{m}}(\mathrm{t})=\mathrm{ER}_{\mathrm{ml}}(\mathrm{t}) / 39.5\end{array}$ & [13] \\
\hline $\begin{array}{l}\text { Nutrient and energy } \\
\text { in maternal body }\end{array}$ & $\begin{array}{l}\mathrm{ER}_{\mathrm{m}}: \text { Total energy content in maternal tissues }(\mathrm{MJ}) \\
\mathrm{ER}_{\mathrm{m}}=-1074+13.65 \mathrm{EBW}+45.94 \mathrm{BF} \\
\text { PROT }_{\mathrm{m}}: \text { Total protein content in maternal tissues }(\mathrm{kg}) \\
\mathrm{PRO}_{\mathrm{m}}=2.28+0.178 \mathrm{EBW}-0.333 .94 \mathrm{~B} \\
\mathrm{LIP}_{\mathrm{m}}: \mathrm{Total}_{\text {energy in maternal tissues }(\mathrm{kg})} \\
\text { LIP }_{\mathrm{m}}=-26.4+0.211 \mathrm{EBW}+1.31 \mathrm{BF}\end{array}$ & [15] \\
\hline
\end{tabular}


Table 2. Main equations describing amino-acids, $\mathrm{Ca}$ and $\mathrm{P}$ utilization by gestating sows

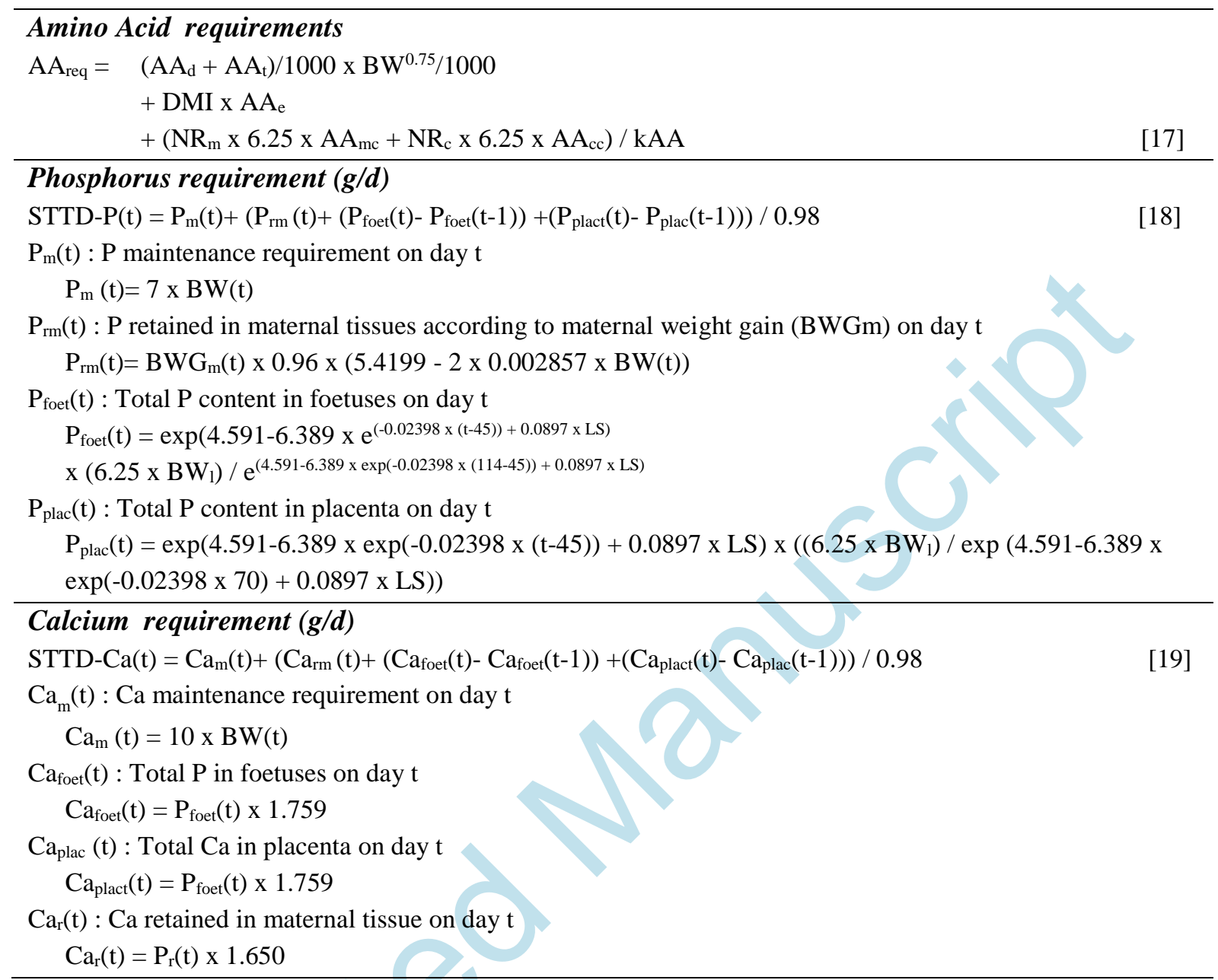

Subscripts and abbreviations: $\mathrm{m}$ : maintenance, $\mathrm{c}$ : conceptus, r: reserves, foet: foetus, plac:

placenta, LS: litter size, t: time (day in pregmancy), $\mathrm{BW}_{1}$ : litter birth body weight of litter $(\mathrm{kg}), \mathrm{AA}_{\mathrm{d}}$ : AA losses due to desquamation $\left(\mathrm{mg} / \mathrm{kg} \mathrm{BW}{ }^{0.75}\right), \mathrm{AA}_{\mathrm{t}}$ : AA losses due to turnover $\left(\mathrm{mg} / \mathrm{kg} \mathrm{BW}{ }^{0.75}\right), \mathrm{AA}_{\mathrm{e}}$ : AA basal endogenous losses $\left(\mathrm{mg} / \mathrm{kg}\right.$ dry matter intake), $\mathrm{NRu}_{\mathrm{c}}$ : conceptus nitrogen retention, $\mathrm{NR}_{\mathrm{m}}$ : maternal nitrogen retention, $\mathrm{AA}_{\mathrm{c}}$ : $\mathrm{AA}$ content in conceptus protein, $\mathrm{AA}_{\mathrm{mc}}$ : maternal AA content in protein, $\mathrm{k}_{\mathrm{AA}}$ : marginal efficiencies ${ }^{1}$ For maintenance, Bikker and Blok (2017) reported a $6 \mathrm{mg} \mathrm{P} / \mathrm{kgBW}$ faecal endogenous losses, $1 \mathrm{mg} \mathrm{P} / \mathrm{kg} \mathrm{BW}$ urinary losses (total of $7 \mathrm{mg} \mathrm{P} / \mathrm{kgBW}$ endogenous losses of P) and 8 $\mathrm{mg} \mathrm{Ca} / \mathrm{kgBW}$ faecal endogenous losses, $2 \mathrm{mg} \mathrm{Ca} / \mathrm{kg} \mathrm{BW}$ urinary losses (total of $10 \mathrm{mg}$ $\mathrm{Ca} / \mathrm{kgBW}$ endogenous losses). 
Table 3. Maximum efficiency of using standardized ileal digestible protein and amino acids for protein deposition in gestating sows, calculated based on the ideal amino acid profile, maintenance requirement and maternal and foetal protein amino acid contents

\begin{tabular}{|c|c|c|c|c|c|c|c|}
\hline AA & $\begin{array}{l}\text { Ideal amino } \\
\text { acid profile }{ }^{4}, \\
\% \text { of Lysine }\end{array}$ & $\begin{array}{l}\text { Integument } \\
\operatorname{loss}^{1}\left(\mathrm{AA}_{\mathrm{d}}\right) \text {, } \\
\mathrm{mg} / \mathrm{kg} \mathrm{BW}^{0.75}\end{array}$ & $\begin{array}{l}\text { Losses due to } \\
\text { basal turnover } \\
\left(\mathrm{AA}_{\text {turn }}\right), \\
\mathrm{mg}^{1} \mathrm{~kg} \mathrm{BW}^{0.75}\end{array}$ & $\begin{array}{l}\text { Basal } \\
\text { endogenous } \\
\operatorname{losses}^{2}\left(\mathrm{AA}_{\mathrm{e}}\right) \text {, } \\
\mathrm{g} / \mathrm{kg} \mathrm{DMI}\end{array}$ & $\begin{array}{l}\text { Content in maternal } \\
\text { body protein }{ }^{3}, \mathrm{~g} / 16 \mathrm{~g} \\
\mathrm{~N}\end{array}$ & $\begin{array}{l}\text { Content in } \\
\text { conceptus } \\
\text { protein }^{4}, \mathrm{~g} / 16 \\
\mathrm{~g} \mathrm{~N}\end{array}$ & $\begin{array}{l}\text { Maximum } \\
\text { efficiency }^{5} \\
\left(\mathrm{k}_{\mathrm{AA}}\right)\end{array}$ \\
\hline \multicolumn{8}{|l|}{ Protein } \\
\hline Lysine & 100 & 4.5 & 23.9 & 0.313 & 6.96 & 5.90 & $0.72^{6}$ \\
\hline Methionine & 28 & 1.0 & 7.0 & 0.087 & 1.88 & 1.40 & 0.67 \\
\hline Methionine + Cystine & 65 & 5.7 & 11.7 & 0.227 & 2.91 & 2.70 & 0.47 \\
\hline Tryptophan & 20 & 0.9 & 3.5 & 0.117 & 0.95 & 1.00 & 0.55 \\
\hline Threonine & 72 & 3.3 & 13.8 & 0.330 & 3.70 & 3.50 & 0.56 \\
\hline Phenylalanine & 60 & 3.0 & 13.7 & 0.273 & 3.78 & 3.40 & 0.69 \\
\hline Phenylalanine + Tyrosine & 100 & 4.9 & 22.7 & 0.496 & 6.64 & 5.80 & 0.73 \\
\hline Leucine & 100 & 5.3 & 27.1 & 0.427 & 7.17 & 6.20 & 0.80 \\
\hline Isoleucine & 65 & 2.5 & 12.4 & 0.257 & 3.46 & 3.00 & 0.55 \\
\hline Valine & 75 & 3.8 & 16.4 & 0.357 & 4.67 & 4.60 & 0.70 \\
\hline Histidine & 32 & 1.3 & 10.2 & 0.130 & 2.79 & 2.30 & 0.96 \\
\hline Arginine & 42 & 0.0 & 0.0 & 0.280 & 6.26 & 6.80 & 1.51 \\
\hline
\end{tabular}

${ }^{1}$ From Moughan (1999),

${ }^{2}$ From Noblet et al. (2004),

${ }^{3}$ From van Milgen et al. (2008), 
${ }^{4}$ From Dourmad et al. (1999)

${ }^{5}$ The maximum marginal efficiencies were calculated based on the assumption that the ideal amino acid profile is adapted for a sow that weights $200 \mathrm{~kg}$, consumes $2.4 \mathrm{~kg} \mathrm{DM} / \mathrm{d}$, with a protein retention of 52 and $23 \mathrm{~g} / \mathrm{d}$ in maternal tissues and conceptus, respectively. The maximum efficiency of lysine above maintenance was set at 0.72 (Dourmad et al., 2002, and NRC, 2012), from which the $\mathrm{k}_{\mathrm{AA}}$ values of the other amino

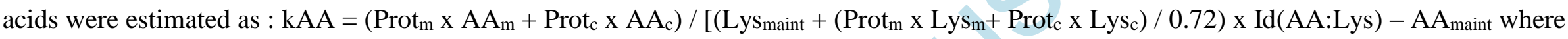
kAA is the marginal efficiency of amino acid "AA", Protm the maternal protein depositiont, Protc the conceptus protein deposition, Id(AA:Lys) the $\mathrm{AA}$ :Lys ratio in the ideal protein for gestation, and $\mathrm{AA}_{\text {maint }}$ the $\mathrm{AA}$ maintenance requirement, calculated as the sum of requirements for desquamation, turnover and endogenous losses. 
Table 4. Description of the database (means \pm SD) used to evaluate the variability of requirement

\begin{tabular}{lccccccc}
\hline Parity & Number of sows & Litter size & Piglets BW, g & $\begin{array}{c}\text { Sow BW } \\
\text { at AI, kg }\end{array}$ & Sow BT at AI, mm & $\begin{array}{c}\text { Target BW } \\
\text { after farrowing, kg }\end{array}$ & $\begin{array}{c}\text { Target BT } \\
\text { after farrowing, mm }\end{array}$ \\
\hline 1 & 392 & $13.3 \pm 2.94$ & $1405 \pm 215$ & $163 \pm 16$ & $17.9 \pm 4.03$ & 203 & 18 \\
2 & 389 & $13.5 \pm 3.12$ & $1557 \pm 233$ & $192 \pm 16$ & $15.9 \pm 3.60$ & 227 & 18 \\
3 & 413 & $14.1 \pm 3.43$ & $1523 \pm 234$ & $211 \pm 17$ & $15.0 \pm 3.44$ & 243 & 18 \\
4 & 384 & $14.9 \pm 3.17$ & $1480 \pm 245$ & $227 \pm 18$ & $14.4 \pm 3.44$ & 255 & 18 \\
5 & 335 & $15.0 \pm 3.09$ & $1472 \pm 215$ & $234 \pm 19$ & $14.1 \pm 3.47$ & 260 & 18 \\
6 & 253 & $14.8 \pm 3.47$ & $1438 \pm 256$ & $241 \pm 20$ & $14.1 \pm 3.40$ & 263 & 18 \\
7 & 187 & $13.9 \pm 3.54$ & $1445 \pm 231$ & $246 \pm 21$ & $14.6 \pm 3.78$ & 265 & 18 \\
8 & 158 & $13.6 \pm 3.77$ & $1455 \pm 247$ & $251 \pm 19$ & $14.9 \pm 3.53$ & 267 & 18 \\
\hline All & 2511 & $14.1 \pm 3.32$ & $1478 \pm 234$ & $214 \pm 18$ & $15.2 \pm 3.59$ & 244 & 18 \\
\hline
\end{tabular}

BW: body weight, BT: backfat thickness, AI: artificial insemination 
Table 5. Means and standard errors of metabolisable energy and sows' composition and mineral requirements regarding litter size and parity, for group-housed sows at $16^{\circ} \mathrm{C}$

\begin{tabular}{|c|c|c|c|c|c|c|c|c|c|c|c|c|c|}
\hline Parity & & 1 & & & 2 & & & $>2$ & & 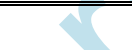 & & P-value & \\
\hline Litter Size & $S$ & $\mathrm{M}$ & $\mathrm{L}$ & $\mathrm{S}$ & $\mathrm{M}$ & $\mathrm{L}$ & $\mathrm{S}$ & $\mathrm{M}$ & $\mathrm{L}$ & SE & Parity & LS & Parity x LS \\
\hline Number of sows & 87 & 221 & 84 & 87 & 204 & 98 & 297 & 738 & 695 & & & & \\
\hline \multicolumn{14}{|l|}{ Metabolizable Energy } \\
\hline $\mathrm{ME}_{\mathrm{c}}, \mathrm{MJ} / \mathrm{d}$ & 0.98 & 1.50 & 1.91 & 1.09 & 1.66 & 2.16 & 1.01 & 1.58 & 2.07 & 0.19 & $<0.01$ & $<0.01$ & 0.41 \\
\hline $\mathrm{ME}_{\mathrm{r}}, \mathrm{MJ} / \mathrm{d}$ & 6.92 & 7.10 & 6.19 & 7.11 & 7.24 & 6.84 & 5.99 & 6.02 & 5.93 & 0.49 & $<0.01$ & $<0.01$ & 0.31 \\
\hline $\mathrm{ME}_{\text {req }}, \mathrm{MJ} / \mathrm{d}$ & 29.8 & 30.8 & 31.2 & 32.7 & 33.6 & 34.5 & 34.6 & 35.6 & 36.3 & 0.28 & $<0.01$ & 0.04 & 0.82 \\
\hline $\mathrm{BW}, \mathrm{kg}$ & 184 & 187 & 197 & 213 & 216 & 225 & 249 & 255 & 258 & 0.10 & $<0.01$ & $<0.01$ & $<0.01$ \\
\hline $\mathrm{ADG}, \mathrm{g} / \mathrm{d}$ & 326 & 394 & 454 & 332 & 413 & 501 & 302 & 387 & 479 & 0.04 & 0.01 & $<0.01$ & 0.01 \\
\hline $\mathrm{LIP}_{\mathrm{M}}, \mathrm{g} / \mathrm{d}$ & 40.3 & 40.8 & 42.9 & 44.9 & 44.9 & 46.4 & 50.4 & 51.2 & 51.5 & 0.08 & $<0.01$ & 0.06 & $<0.01$ \\
\hline $\mathrm{PROT}_{\mathrm{M}}, \mathrm{g} / \mathrm{d}$ & 26.7 & 26.3 & 27.1 & 32.2 & 31.6 & 32.4 & 39.4 & 39.2 & 39.0 & 0.05 & $<0.01$ & 0.17 & $<0.01$ \\
\hline $\mathrm{NR}, \mathrm{g} / \mathrm{d}$ & 10.8 & 12.4 & 13.2 & 10.2 & 11.8 & 13.3 & 8.24 & 9.58 & 11.2 & 0.03 & $<0.01$ & $<0.01$ & $<0.01$ \\
\hline \multicolumn{14}{|l|}{ Minerals requirements } \\
\hline STTD-P, g/d & 2.85 & 3.24 & 3.61 & 3.07 & 3.52 & 4.01 & 3.16 & 3.63 & 4.10 & 0.18 & $<0.01$ & $<0.01$ & 0.36 \\
\hline STTD-P, g/kg & 1.23 & 1.36 & 1.48 & 1.21 & 1.35 & 1.49 & 1.18 & 1.31 & 1.45 & 0.07 & $<0.01$ & $<0.01$ & 0.96 \\
\hline Total-Ca, g/kg & 3.85 & 4.28 & 4.71 & 3.78 & 4.25 & 4.72 & 3.64 & 4.1 & 4.57 & 0.24 & $<0.01$ & $<0.01$ & 0.97 \\
\hline Ratio Total-Ca/ STTD-P & 3.11 & 3.13 & 3.14 & 3.09 & 3.12 & 3.13 & 3.06 & 3.09 & 3.11 & 0.01 & $<0.01$ & $<0.01$ & 0.01 \\
\hline
\end{tabular}

Subscripts and abbreviations: $\mathrm{m}$ : maintenance, c: conceptus, r: maternal reserves, ML: maternal lipids, MP: maternal proteins, Litter Size: $\mathrm{S}=$ small litter $<12$ piglets, $\mathrm{M}=$ average litter $<16$ piglets and $\geq 12, \mathrm{~L}=$ large litter $\geq 16$ piglets, ME: Metabolizable Energy $(\mathrm{MJ} / \mathrm{d}), \mathrm{ME}$ : $\mathrm{ME}$ for maintenance, $\mathrm{ME}_{\mathrm{r}}$ : ME for maternal body reserves (lipids: $\mathrm{ML}$ and proteins: $\mathrm{MP}$ ), $\mathrm{ME}_{\mathrm{c}}$ : ME for conceptus (placenta, foetuses, liquids), $\mathrm{ME} \mathrm{E}_{\mathrm{t}}$ ME for thermoregulation (in this case at $\left.16^{\circ} \mathrm{C}\right)$, NR: Total nitrogen retention $(\mathrm{g} / \mathrm{d}), \mathrm{BW}$ : body weight $(\mathrm{kg}), \mathrm{BWg}$ : Body weight gain (g/d), PROT $\mathrm{M}$ : maternal protein gain $(\mathrm{g} / \mathrm{d}), \mathrm{LIP}_{\mathrm{M}}$ : maternal lipid gains $(\mathrm{g} / \mathrm{d})$. 
Table 6. Effect of parity and litter size on average SID AA requirement of gestating sows housed in thermoneutral conditions.

\begin{tabular}{|c|c|c|c|c|c|c|c|c|c|c|c|c|c|}
\hline \multirow{2}{*}{$\begin{array}{l}\text { Parity } \\
\text { Litter Size }\end{array}$} & \multicolumn{3}{|c|}{1} & \multicolumn{3}{|c|}{2} & \multicolumn{3}{|c|}{3} & \multirow[b]{2}{*}{ SE } & \multicolumn{3}{|c|}{ P-value } \\
\hline & $S$ & M & $\mathrm{L}$ & $S$ & $\mathrm{M}$ & $\mathrm{L}$ & $S$ & $\mathrm{M}$ & $\mathrm{L}$ & & Parity & LS & Parity x LS \\
\hline AA req., g/d & & & & & & & & & & & & & \\
\hline Lysine & 7.76 & 8.75 & 9.33 & 7.71 & 8.71 & 9.64 & 6.95 & 7.79 & 8.79 & 0.12 & $<0.01$ & $<0.01$ & 0.04 \\
\hline Threonine & 5.79 & 6.51 & 6.89 & 5.73 & 6.45 & 7.09 & 5.14 & 5.73 & 6.43 & 0.09 & $<0.01$ & $<0.01$ & 0.04 \\
\hline Methionine & 2.07 & 2.35 & 2.52 & 2.07 & 2.35 & 2.62 & 1.88 & 2.12 & 2.41 & 0.03 & $<0.01$ & $<0.01$ & 0.06 \\
\hline Cysteine & 3.31 & 3.68 & 3.85 & 3.23 & 3.6 & 3.91 & 2.85 & 3.14 & 3.48 & 0.04 & $<0.01$ & $<0.01$ & 0.04 \\
\hline Tryptophan & 1.67 & 1.86 & 1.96 & 1.65 & 1.84 & 2.01 & 1.47 & 1.63 & 1.82 & 0.02 & $<0.01$ & $<0.01$ & 0.04 \\
\hline Isoleucine & 5.07 & 5.72 & 6.09 & 5.01 & 5.68 & 6.28 & 4.48 & 5.03 & 5.69 & 0.08 & $<0.01$ & $<0.01$ & 0.04 \\
\hline Leucine & 7.85 & 8.78 & 9.33 & 7.85 & 8.79 & 9.67 & 7.19 & 7.99 & 8.93 & 0.11 & $<0.01$ & $<0.01$ & 0.05 \\
\hline Valine & 6.13 & 6.85 & 7.24 & 6.07 & 6.80 & 7.45 & 5.48 & 6.08 & 6.79 & 0.09 & $<0.01$ & $<0.01$ & 0.04 \\
\hline Phenylalanine & 4.75 & 5.33 & 5.66 & 4.73 & 5.31 & 5.84 & 4.29 & 4.78 & 5.35 & 0.07 & $<0.01$ & $<0.01$ & 0.05 \\
\hline Histidine & 2.48 & 2.78 & 2.95 & 2.48 & 2.78 & 3.07 & 2.29 & 2.54 & 2.85 & 0.03 & $<0.01$ & $<0.01$ & 0.06 \\
\hline Arginine & 3.53 & 3.99 & 4.2 & 3.41 & 3.88 & 4.26 & 2.91 & 3.28 & 3.72 & 0.06 & $<0.01$ & $<0.01$ & 0.03 \\
\hline AA req., g/kg & & & & & & & & & & & & & \\
\hline Lysine & 3.35 & 3.65 & 3.82 & 3.04 & 3.34 & 3.57 & 2.60 & 2.82 & 3.10 & 0.04 & $<0.01$ & $<0.01$ & 0.10 \\
\hline Threonine & 2.50 & 2.71 & 2.82 & 2.26 & 2.47 & 2.63 & 1.91 & 2.07 & 2.27 & 0.03 & $<0.01$ & $<0.01$ & 0.07 \\
\hline Methionine & 0.90 & 0.98 & 1.03 & 0.82 & 0.90 & 0.97 & 0.70 & 0.77 & 0.85 & 0.01 & $<0.01$ & $<0.01$ & 0.14 \\
\hline Cysteine & 1.43 & 1.54 & 1.58 & 1.28 & 1.38 & 1.45 & 1.06 & 1.13 & 1.23 & 0.01 & $<0.01$ & $<0.01$ & 0.03 \\
\hline Tryptophan & 0.72 & 0.78 & 0.80 & 0.65 & 0.71 & 0.75 & 0.55 & 0.59 & 0.64 & 0.01 & $<0.01$ & $<0.01$ & 0.05 \\
\hline Isoleucine & 2.19 & 2.38 & 2.50 & 1.98 & 2.17 & 2.33 & 1.67 & 1.82 & 2.01 & 0.02 & $<0.01$ & $<0.01$ & 0.09 \\
\hline Leucine & 3.39 & 3.66 & 3.82 & 3.10 & 3.37 & 3.59 & 2.69 & 2.89 & 3.15 & 0.03 & $<0.01$ & $<0.01$ & 0.11 \\
\hline Valine & 2.65 & 2.85 & 2.97 & 2.40 & 2.61 & 2.76 & 2.04 & 2.19 & 2.40 & 0.02 & $<0.01$ & $<0.01$ & 0.07 \\
\hline Phenylalanine & 2.05 & 2.23 & 2.31 & 1.87 & 2.03 & 2.17 & 1.60 & 1.72 & 1.89 & 0.02 & $<0.01$ & $<0.01$ & 0.09 \\
\hline Histidine & 1.07 & 1.16 & 1.21 & 0.98 & 1.07 & 1.14 & 0.86 & 0.92 & 1.00 & 0.01 & $<0.01$ & $<0.01$ & 0.13 \\
\hline Arginine & 1.52 & 1.66 & 1.72 & 1.35 & 1.48 & 1.58 & 1.08 & 1.18 & 1.31 & 0.02 & $<0.01$ & $<0.01$ & 0.04 \\
\hline Ratio Thr/Lys & 0.75 & 0.74 & 0.74 & 0.75 & 0.74 & 0.74 & 0.74 & 0.74 & 0.73 & 0.01 & $<0.01$ & $<0.01$ & 0.59 \\
\hline
\end{tabular}

Litter Size: $\mathrm{S}=$ small litter $<12$ piglets, $\mathrm{M}=$ average litter $<16$ piglets and $\geq 12, \mathrm{~L}=$ large litter $\geq 16$ piglets 
Table 7. Means and standard errors of energy required for thermoregulation, digestible lysine, threonine, STTD-P and Total-Ca requirements for gestating sows housed in groups at different temperatures $\left(12\right.$ vs. $\left.16^{\circ} \mathrm{C}\right)$

\begin{tabular}{lcccc}
\hline & at $16^{\circ} \mathrm{C}$ & at $12^{\circ} \mathrm{C}$ & SE & P-value $^{1}$ \\
\hline $\begin{array}{l}\text { Thermoregulation, MJ ME/d } \\
\text { Requirements in g/d }\end{array}$ & 0 & 1.96 & 0.01 & $<0.01$ \\
$\quad$ Lys, g/d & & & & \\
Thr, g/d & 8.25 & 8.29 & 0.03 & $<0.01$ \\
STTD-P, g/d & 6.07 & 6.12 & 0.02 & $<0.01$ \\
Total-Ca, g/d & 3.62 & 3.64 & 0.01 & $<0.01$ \\
Requirements in g/kg & 11.37 & 11.39 & 0.04 & $<0.01$ \\
Lys, g/kg & & & & \\
Thr, g/kg & 3.08 & 2.92 & 0.01 & $<0.01$ \\
STTD-P, g/kg & 2.27 & 2.16 & 0.01 & $<0.01$ \\
Total-Ca, g/kg & 1.35 & 1.28 & 0.51 & $<0.01$ \\
& 4.23 & 4.01 & 0.01 & $<0.01$ \\
\hline
\end{tabular}

${ }^{1}$ Week always had a significant $\mathrm{P}$-value $(\mathrm{P}<0.01)$ as described previou 
Figure 1

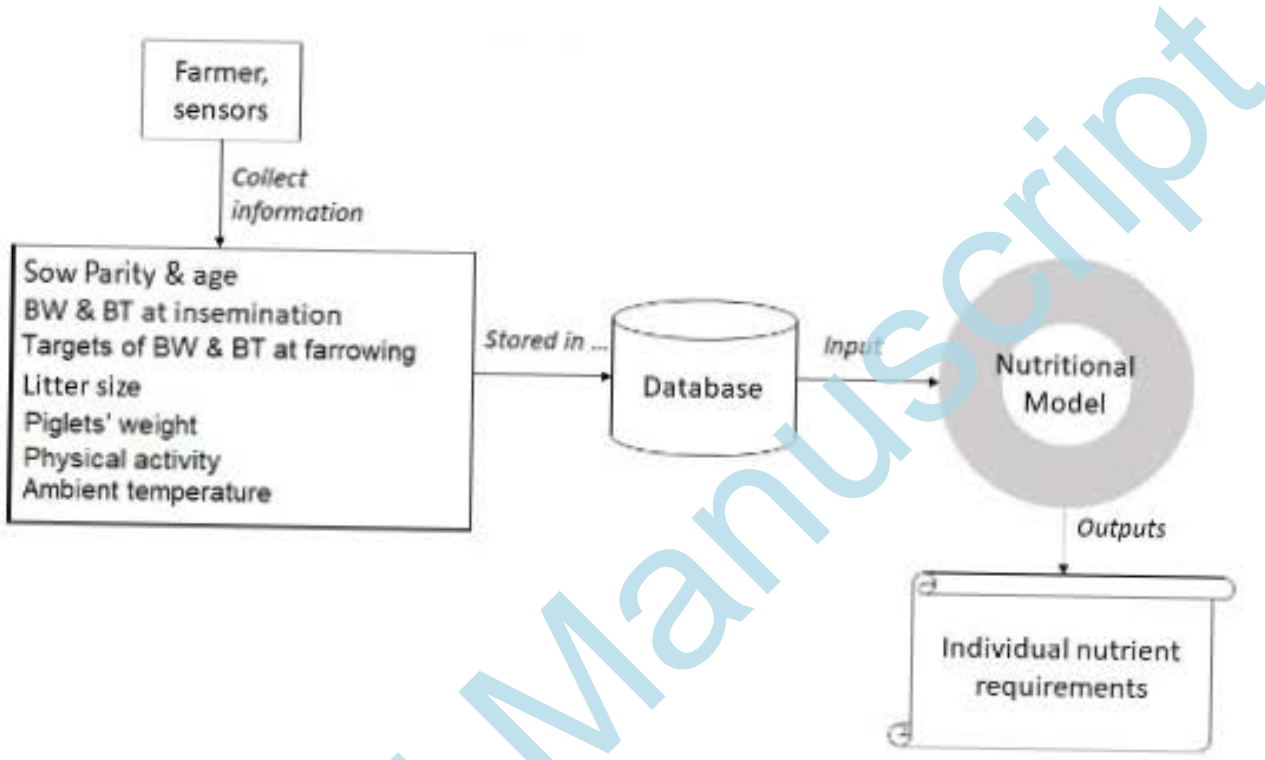


Figure 2

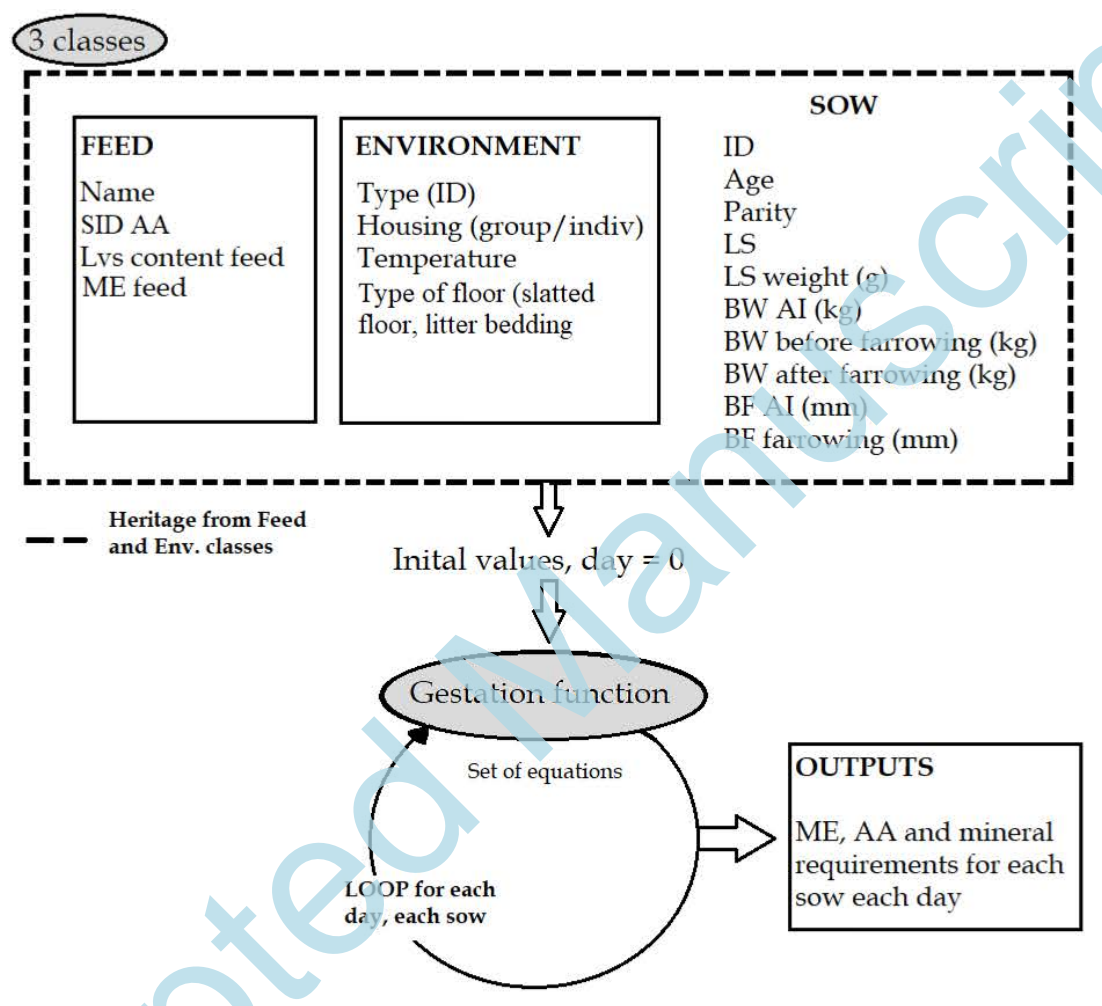


Figure 3

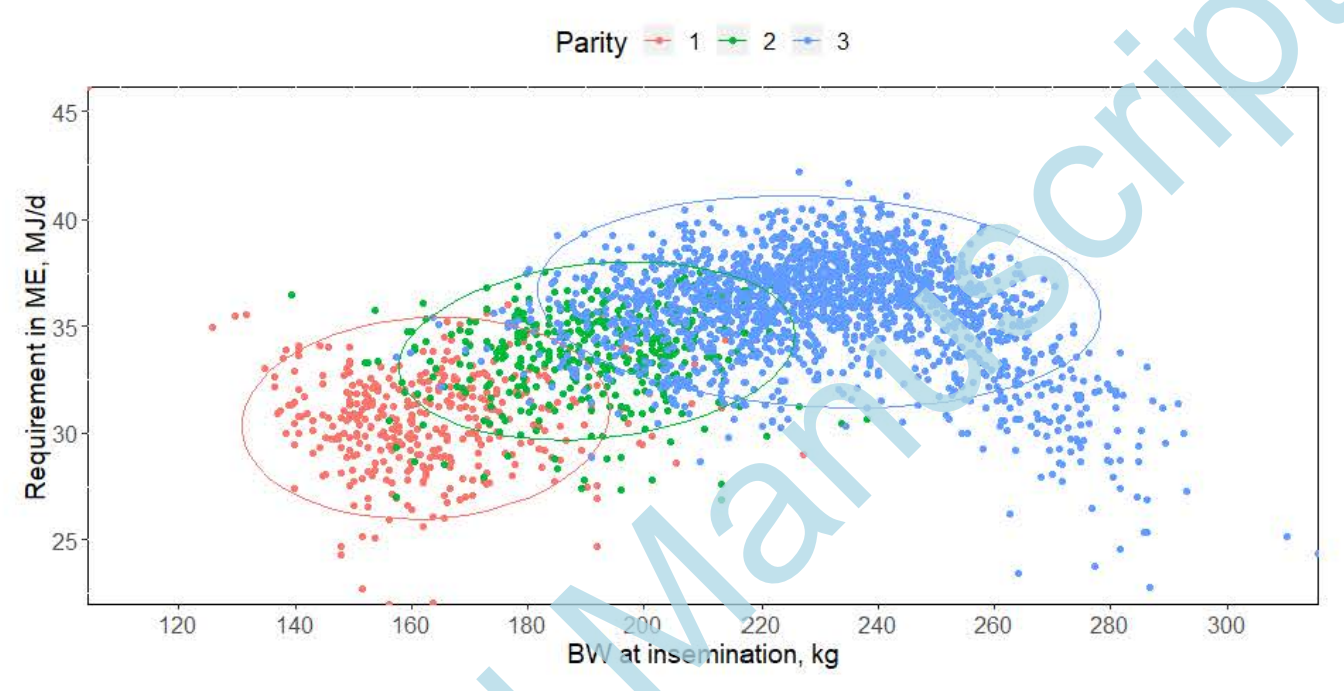


Figure 4

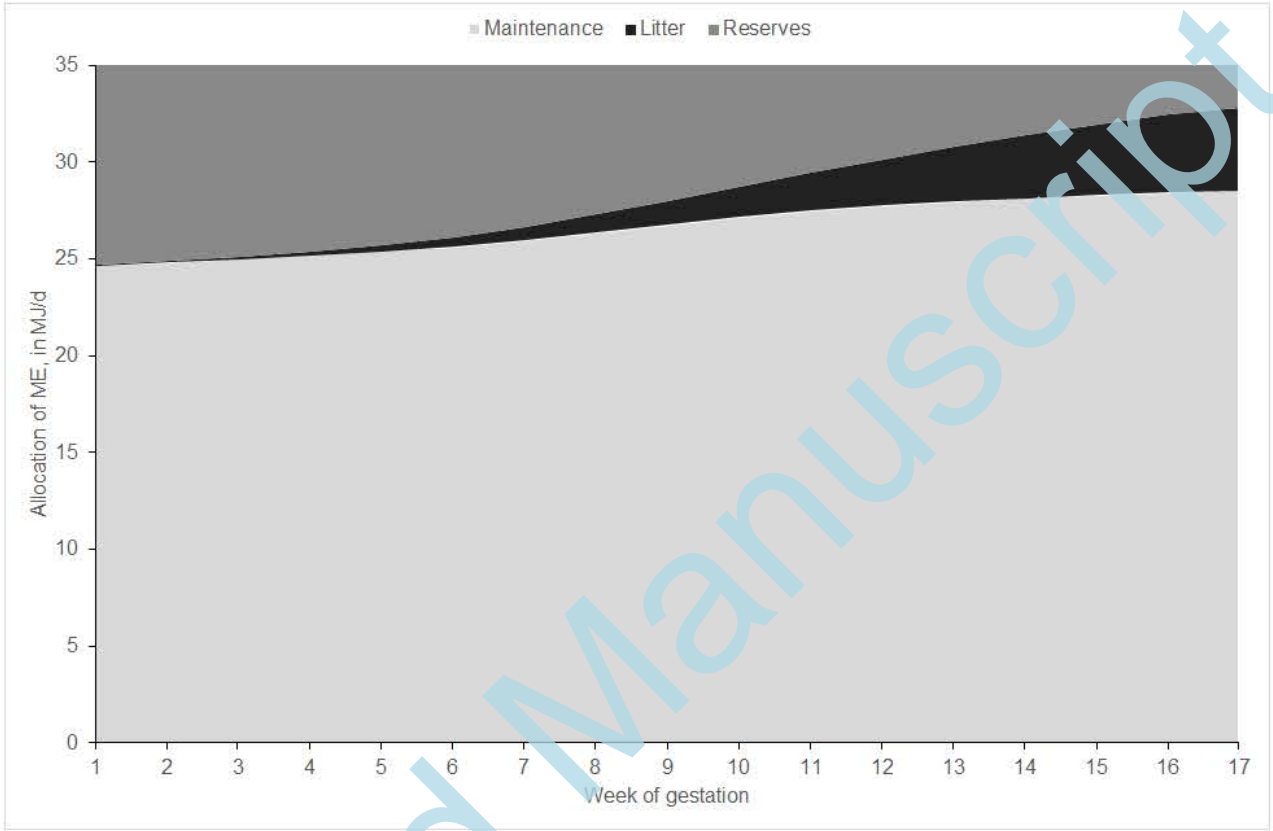


Figure 5

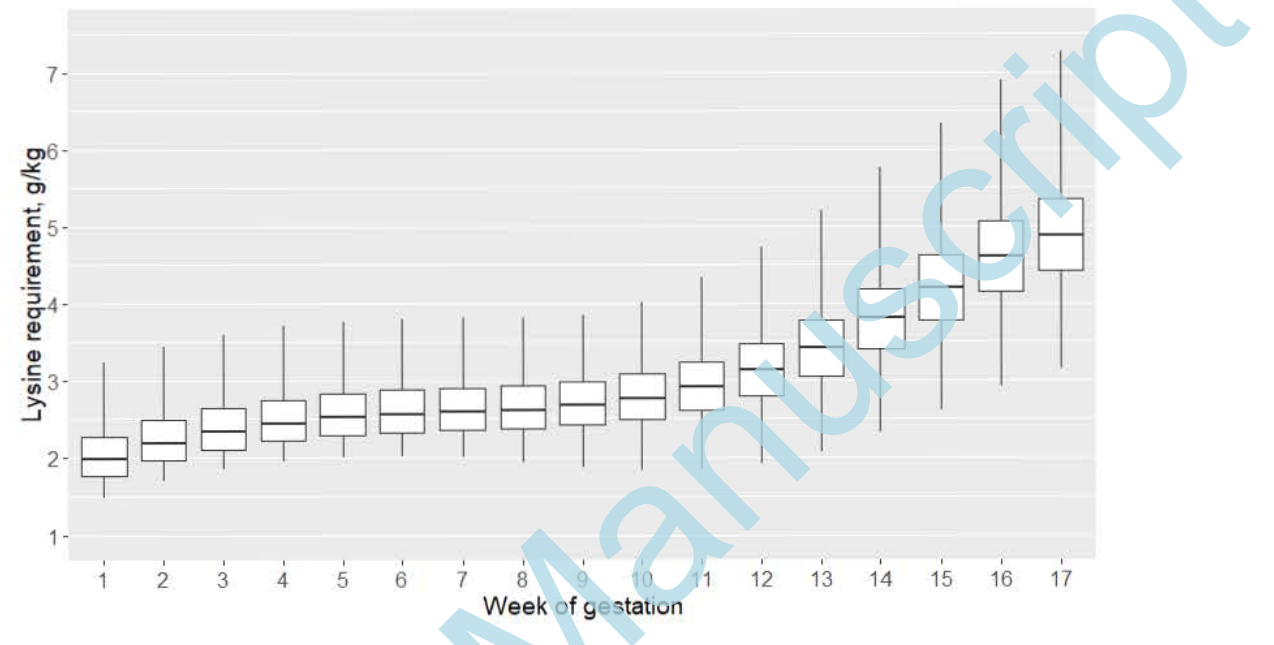


Figure 6

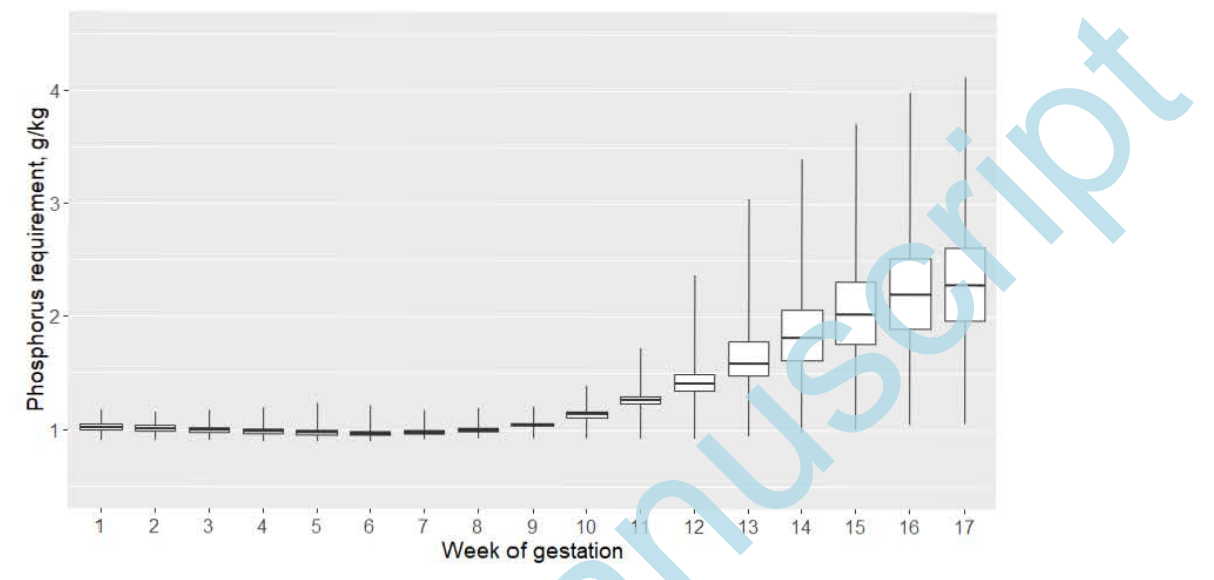


Figure 7a

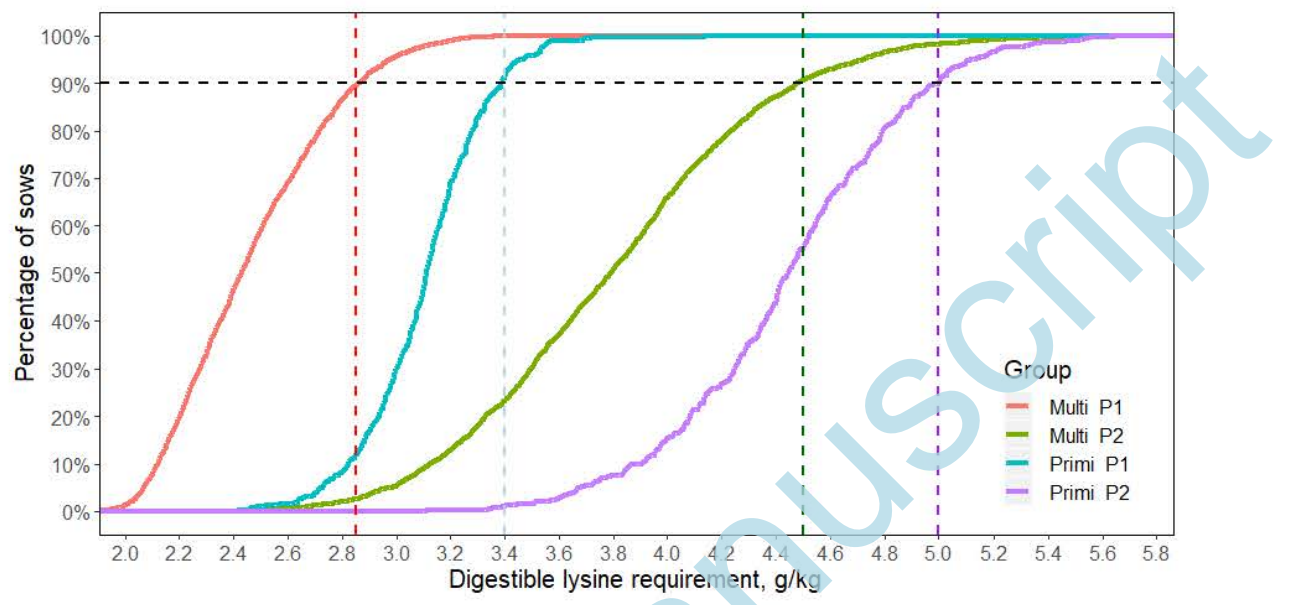


Figure 7b

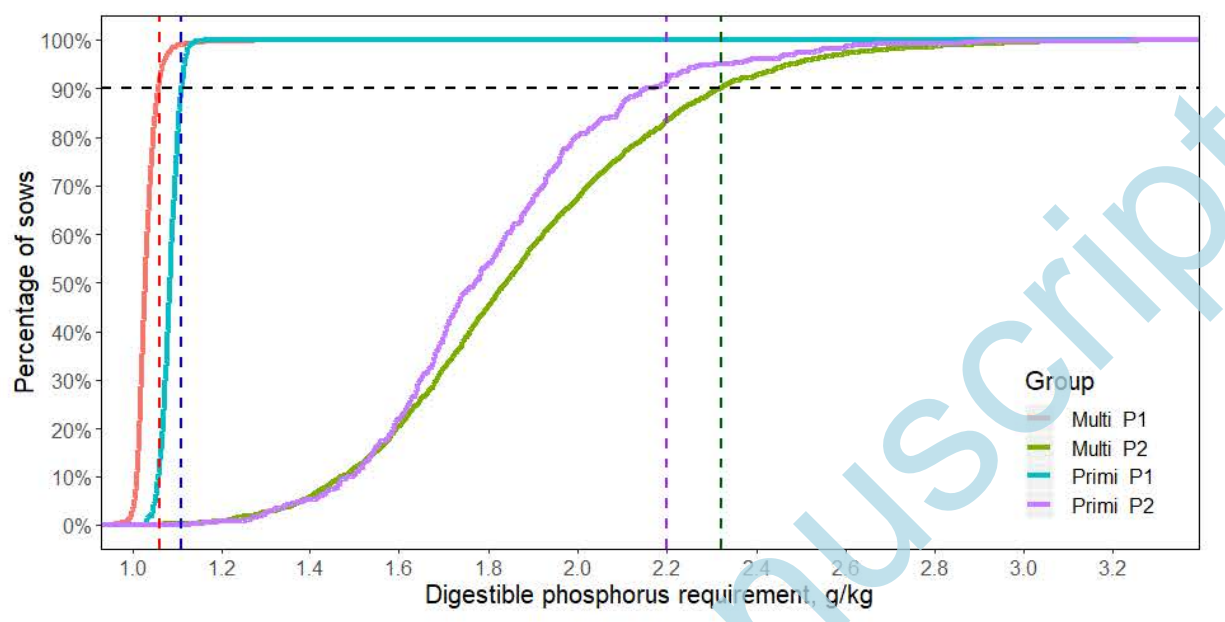


Figure 8

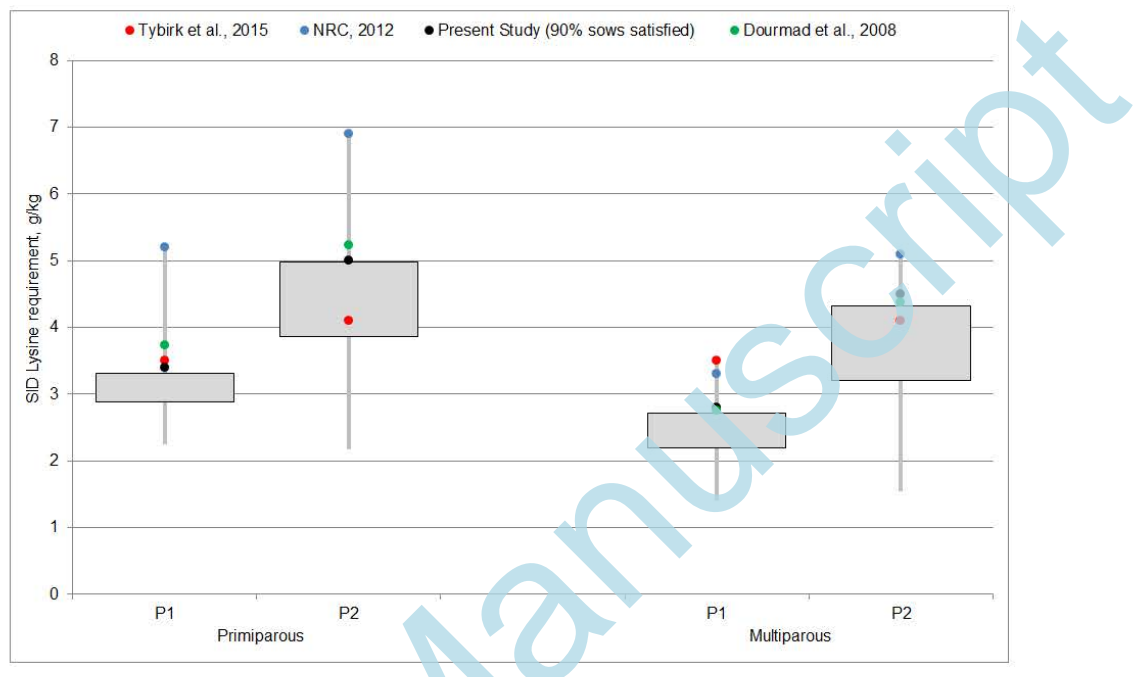

